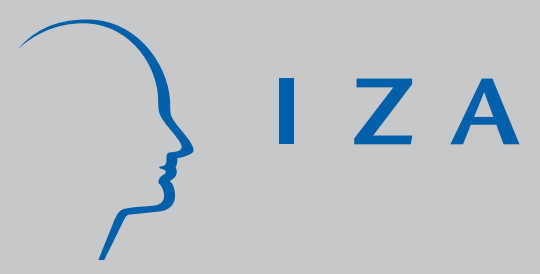

IZA DP No. 3319

Segregation, Entrepreneurship and Work Values: The Case of France

Claudia Senik

Thierry Verdier

J anuary 2008 


\title{
Segregation, Entrepreneurship and Work Values: The Case of France
}

\author{
Claudia Senik \\ Paris School of Economics, \\ University Paris IV and IZA \\ Thierry Verdier \\ Paris School of Economics, \\ University of Southampton and CEPR \\ Discussion Paper No. 3319 \\ January 2008 \\ IZA \\ P.O. Box 7240 \\ 53072 Bonn \\ Germany \\ Phone: +49-228-3894-0 \\ Fax: +49-228-3894-180 \\ E-mail: iza@iza.org
}

Any opinions expressed here are those of the author(s) and not those of IZA. Research published in this series may include views on policy, but the institute itself takes no institutional policy positions.

The Institute for the Study of Labor (IZA) in Bonn is a local and virtual international research center and a place of communication between science, politics and business. IZA is an independent nonprofit organization supported by Deutsche Post World Net. The center is associated with the University of Bonn and offers a stimulating research environment through its international network, workshops and conferences, data service, project support, research visits and doctoral program. IZA engages in (i) original and internationally competitive research in all fields of labor economics, (ii) development of policy concepts, and (iii) dissemination of research results and concepts to the interested public.

IZA Discussion Papers often represent preliminary work and are circulated to encourage discussion. Citation of such a paper should account for its provisional character. A revised version may be available directly from the author. 
IZA Discussion Paper No. 3319

January 2008

\section{ABSTRACT}

\section{Segregation, Entrepreneurship and Work Values: The Case of France ${ }^{*}$}

This paper studies the interaction between labor market integration, the evolution of "work values" and entrepreneurial capital inside minority communities. A simple model of labor market segmentation with ethnic capital and endogenous transmission of cultural values inside the minority group is presented. It emphasizes the role of entrepreneurial capital as an important driver of labor market integration and as a promoter of meritocratic work values inside the community. The case of South European and North African second generation immigrants in France is then empirically studied as an example, contrasting strongly how the differential economic and cultural integration in the labor market correlates with the differential level of entrepreneurial capital of the two communities.

JEL Classification: J15, J61, J7, Z13

Keywords: social capital, ethnic segmentation, work values, labor discrimination

Corresponding author:

Claudia Senik

Paris School of Economics

48 bd Jourdan

75014 Paris

France

E-mail: senik@pse.ens.fr

\footnotetext{
* We thank the Lasmas-IDL (centre Maurice Halbwachs) for providing the 1999 French Census data 1999; we are grateful to Eric Maurin, Hélène Garner, Dominique Meda and Michel Gollac for their useful remarks.
} 


\section{Introduction}

An intense political and intellectual debate is taking place in Europe around migration issues. A major challenge relates to the process of labor market integration or segregation of immigrants in the host economy. This issue is at the forefront of the policy agenda of many western governments.

An illustrative example is France where the segmentation of the labor market is nowadays one of the most important issues for the population and a major political challenge for the government. This aspect is actually compounded by the ethnic divide along which it is sometimes thought to operate. In particular, the difficulties that immigrants from North Africa encouter on the French labor market are well-documented. They have been shown to be both salient and in sharp contrast with the situation of other immigrants, e;g. immigrants from Southern Europe (Okba and Laine, 2004, Silberman and Fournier, 2006, 2007, Joseph and Lemiere, 2005). Local concentration of youth unemployment and urban unrest are the symptoms of this growing problem. For some observers, this reveals the failure of the French republican model of social integration. For others, it simply confirms the idea that particular minority groups have intrinsically "cultural difficulties" to assimilate and integrate into the French socio-economic system. With respect to labor market issues, it is argued that, beyond traditional individual socio-economic characteristics, differential rates of success in the labor market across communities may actually be explained by differences in work values and job identity norms attached to the communities ${ }^{1}$.

While plausible at a given point of time, this "culturalist explanation" has been attacked for its lack of dynamic perspective (Knocke, 2000). As a matter of fact it leaves open the question of the sources of the differences in work values and job norms in the first place and how these cultural elements tend to persist or change over time within minority groups. In a dynamic perspective, an essential question is to understand how labor market segregation and work values co-evolve within groups and how they jointly determine employment outcomes. The purpose of this paper is to investigate this issue both theoretically and empirically, focusing on the interaction between labor market segmentation, the transmission of work values and the importance of ethnic entrepreneurial capital inside minority groups.

More specifically, we start from the idea that ethnic segregation can be based on both positive and negative motivations. One type of reason is solidarity, common destiny, shared adversity. But many surveys also put in evidence the central role of information, monitoring and control inside an ethnic group. In the limits of a small community, information is easier to acquire. The higher proximity of agents allows a better mutual knowledge and a control exerted by everyone on everyone else, hence a greater efficiency of the management of labour resources. By reducing problems of information and con-

\footnotetext{
${ }^{1}$ Along this culturalist explanation line, see for instance Ram and Jones (1998) Barrett, Jones and Mc Evoy (1996), Wilson and Portes (1980) for the case of South Asian ethnic business in Britain.
} 
trol, proximity reduces the management costs imposed by moral hazard, not only in employment relations, but also in financing relations (Portes and Sensenbrenner, 1993). Hence, labour market segmentation is often associated with the constitution of a specific ethnic social capital, which influences the integration of immigrants (Portes ed., 1995). Spatial and professional segregation, in turn, generate their own externalities: imitation, signal sharing (stigma), diffusion of values and attitudes, etc. By determining the scope of work values transmitted to the members of an ethnic minority, ethnic segregation can be self-reinforcing. At the same time, the process of cultural transmission within a minority group can also generate unfavourable features such as stigma and statistical discrimination if the work values and attitudes of the group, as perceived by external observers, are less productivity-prone (Phelps, 1972, Stiglitz, 1973).

The paper tries to embody these different elements in a general view of labour market integration of ethnic minorities. More precisely, we try to put in evidence the central role of entrepreneurship in both the social capital and the genesis of work values of ethnic minorities. To do this, we present a simple model that discusses such dynamics. Assuming a certain degree of ethnic discrimination on the "primary" general labour market and the existence of a "secondary" ethnic labor market, the model shows how ethnic entrepreneurial density, by protecting self-employed individuals from unemployment, can play a crucial role in the transmission of work values, and therefore on the professional integration of workers of foreign origin. We then illustrate the assumptions and predictions of the model using an original French survey designed to study the work attitudes of the French population and of its components in terms of immigration trends: Histoire de Vie (INSEE, 2003). We also use the 1999 French population census, which reports the origin, nationality and occupation of the inhabitants of each French region. Our identification strategy is then based on the regional variation in the density of ethnic entrepreneurship.

French data offer a vision of the French labour market as an ethnically segmented one. A first naïve look at the raw data shows the particular situation of the North African minority on the French labour market. Immigrants from this region are particularly poorly integrated in the labour market; they experience higher rates of unemployment and more instability; they also seem to attach less importance to their job, to consider their job as a more minor motive of identity and to be less satisfied with it. These stylized facts concerning the objective working conditions and the subjective work values of immigrants from Maghreb immediately point to two possible explanations: discrimination and cultural factors.

This paper shows that the story is more subtle. Once the social capital specific to each group of immigrants is taken into account, the specificity of immigrants from North Africa in terms of work values totally disappears (it becomes statistically insignificant) or is even reversed. Indeed, concerning the subjective statement that "work is important as compared to other aspects of life", it appears that immigrants, including the North African minority, attach more importance to work than French natives, once the effect 
of the "ethnic" social capital is controlled for.

These findings suggest that ethnic social capital plays an important role in shaping people's attitude towards work, and that entrepreneurial capital may be a key element of social capital. Hence, work values and attitudes are not mechanically transmitted from generation to generation, but depend on the professional structure of each group of immigrants. Labour market segmentation, entrepreneurship and work values are closely intertwined, potentially generating dramatically different trajectories across minority groups. Given a particular macroeconomic environment, depending on their initial conditions, minority groups may end up in vary different long run situations in terms of labor market integration, entrepreneurship and work values. Our analysis suggests that this could partly explain the different modalities taken by these aspects in the various groups of immigrants in France.

It should however immediately be mentionned that these mechanisms do not constitute a substitute to other explanations in terms of ethnic discrimination. Rather both types of phenomena must be seen as complementary. Indeed, network effects potentially reinforce (or reduce) the stigma attached to each minority group, depending on the latter's record in terms of labour market integration. Discrimination can also reduce the motivation to work of concerned agents by creating the expectation that whatever their effort, the pay-off will remain low. Hence, the policy recommendation that would be consistent with the view supported by this paper is not to minimize the importance of discrimination, but to suggest an additional entry for public policy

The paper is related to various strands of the literature. First, there is a vast sociological literature investigating the role of ethnic entrepreneurship in the pattern of labor market integration of immigrants. Two main hypotheses are generally confronted. The first one is the so-called "step-ladder argument", maintaining that immigrants' employment in ethnic labor markets and co-ethnic firms is a way to acquire knowledge, experience and further access into the "primary" general labor market (Portes and Bach 1985, Portes and Manning 1986, Waldinger 1993). The alternative view is the "ethnic enclave" view, in which ethnic self-employment comes as the result of (expected or ex post) discrimination in the "primary" labor market and provides an avenue for economic mobility in a "protected or privileged" market (Aldrich and al.1981). Our analysis suggests that the two views can be somehow reconciled in the sense that through the profile of labor integration that it sustains, ethnic entrepreneurial capital promotes, as a by product, the transmission of work values, which in turn help immigrants to better integrate into the "primary general" labor market. Hence ethnic self-employment is at the same time a shelter against labor market discrimination and a step towards better integration in the future.

The paper is also obviously related to the economic literature on ethnic capital, migration, and intergenerational mobility. As shown for instance by Borjas $(1992,1995)$, skills transmitted to the next generation of immigrants depend not only on parental 
investment but also on the ethnic capital of the community. This helps explaining the differential rate of economic success of ethnic minorities in the US. Similarly, in our framework, ethnic entrepreneurship capital interacts with the process of transmission of work values inside the group, leading therefore to persistently different trajectories of ethnic minorities, depending on their initial conditions.

Finally, the paper is closely related to the literature on cultural transmission and socialization (Bisin and Verdier 2000, 2001) and its extensions to labor market discrimination and work habits as developed in Saez-Marti and Zenou (2005). This piece of work is closest to this paper. It also investigates the dynamics of work values and the implications for labor market discrimination. Our paper differs from theirs in two dimensions. First, we emphasize the role of parents' employment status in the process of transmission of work values, while their model uses an extended version of the socialization model of Bisin and Verdier (2001) with endogenous transmission rates chosen by parents who decide to transmit purposefully their own trait to their offsprings. Second, we explicitly take into account the co-evolution between ethnic capital, ethnic self-employment and work values, as a mechanism to further labor market integration in the "primary" labor market.

\section{A simple model of labor market participation and cultural evolution}

In this section, we present a simple model linking the cultural evolution of work values, integration in the labor market and entrepreneuship in a minority group. The basic idea is to emphasize the fact that labor markets are segmented because of differential access to information and enforcement capacity of firms and employers. Our starting point is to assume a "primary" labor market pool in which employers do not have access to relevant information on individual workers' characteristics and face a moral hazard problem. In such a market, employers base their hiring decisions on workers' expected productivity. As such they use group observable characteristics (ie. geographical origin) to infer that level of average productivity. When workers are substitute enough to each other, the result is statistical discrimination across groups in access to jobs.

At the same time, we assume that workers may also be employed in their own ethnic group (an "ethnic enclave" labor market). In this informal/ethnic labor market however, employers know all the relevant individual characteristics of their fellow ethnic members and have access to an efficient monitoring technology mitigating the moral hazard problem. The differentiation between the two labor market pools can be justified in the following way. First, the ethnic labor market is directly related to close-knit community links and networking which allow for fluid informational flows among members, eliminating therefore the asymmetry of information problem on individual productivity. Second, within such networks, reputational concerns and threats of ostracization are important 
devices that provide efficient means to monitor and solve problems of moral hazard in labor relationships ${ }^{2}$.

\subsection{Functioning of the primary labor market:}

More precisely, we assume that the "primary" labor market is characterized in the following way. There is one homogenous numeraire good produced under competitive conditions and using some fixed factor of production $K_{G}$ and unskilled efficient units of labor $H$, with a standard constant return to scale production technology $Q=F\left(K_{G}, H\right)$ ${ }^{3}$. In this labor market, workers are paid a fixed wage $\bar{w}^{4}$

There are two types of workers in this market. First there is a so-called "majority" group, reflecting the majority of workers in society. Second, there is a particular minority group which can be distinguished from the "majority" workers using a publicly observable characteristic (e;g. ethnic origin, language accent or way of speaking), the size of which is normalized to 1 . Whatever the group, each worker has an individual characteristic related to his "work values" or disutility of work effort. For simplicity, we assume that this characteristic can only take two possible values $\theta_{L}$ and $\theta_{H}$ with $\theta_{L}<\theta_{H}$ and is not observable to a firm operating in the "general" labor market. More precisely, when employed on a task, a worker can undertake an effort which costs him a disutility $\theta=\theta_{L}$ or $\theta_{H}$. When the effort is secured, with probability 1 , the worker is productive and he supplies one unit of efficient labor. When no specific effort is undertaken, the worker is only productive with probability $p<1$. We assume that with some probability $\delta>0$, the employer can observe ex post the performance of the worker and fire the worker if he were not productive. The incentive constraint that induces effort is then simply given by:

$$
w-\theta \geq w(1-\delta(1-p))
$$

or

$$
w>\frac{\theta}{(1-p) \delta}
$$

To make things interesting we assume that

$$
\text { Assumption } 1: \frac{\theta_{L}}{(1-p) \delta}<\bar{w}<\frac{\theta_{H}}{(1-p) \delta}
$$

\footnotetext{
${ }^{2}$ Another aspect is that "ethnic" employers are themselves submitted to a certain pressure to hire workers of the same group; the other facet of "social capital" in a way.

${ }^{3}$ We assume for simplicity that $F$ satisfies the Inada conditions $F_{L}\left(K_{G}, 0\right)=+\infty$ and $F_{L}\left(K_{G}, \infty\right)=0$

${ }^{4}$ Uemployment is a the heart of the model. A fixed minimum wage is a simple device to generate the labor market rigidity that generates such a result. At the cost of increased analytical complexity, one could have introduced other specifications (efficiency wages or unions wage bargaining) without altering the basic conclusions of the paper.
} 
namely that at the fixed wage $\bar{w}$, the high "work value" worker (ie. with $\theta_{L}$ ) provides the effort and is productive while the low "work value" individual (ie.. with $\theta_{H}$ ) does not undertake the effort ${ }^{5}$. We denote by $q$ (and $Q$ respectively) the proportion of workers in the "minority" ("majority") group with characteristic $\theta_{L}$. When hiring $L_{1}$ of workers from the "minority" group and $L_{M}$ from the "majority" group, the profit of the typical representative firm in this market writes as:

$$
\begin{aligned}
\Pi\left(K_{G}, L_{1}, L_{M}\right)= & F\left(K_{G},(q+(1-q) p) L_{1}+(Q+(1-Q) p) L_{M}\right) \\
& -\bar{w}[1-(1-q)(1-p) \delta] L_{1}-\bar{w}[1-(1-Q)(1-p) \delta] L_{M}
\end{aligned}
$$

In the minority group, only individuals with characteristic $\theta_{L}$ are providing an effort. Hence $(q+(1-q) p) L_{1}$ is the expected number of productive labor units provided by employing $L_{1}$ workers from that group. At the same time, $\bar{w}[1-(1-q)(1-p) \delta] L_{1}$ is the wage bill, given that the employer does not pay wages for all "lazy" workers (in proportion $1-q$ ) who are unproductive (with probability $1-p$ ) and found to be so (with probability $\delta$ ). Similarly, $(Q+(1-Q) p) L_{M}$ is the expected number of productive labor units provided by employing $L_{M}$ workers from the "majority" group and $\bar{w}[1-(1-Q)(1-p) \delta] L_{M}$ is the wage bill for that group. Maximization of profits give immediately the labor demand or workers. Denote for this $\Psi($.$) the function such that$ for all $x, F_{L}(1, \Psi(x))=x$ It is immediate to see that $\Psi($.$) is a decreasing function. Then$ the first order conditions of profit maximization provide imediately:

$$
\begin{array}{ll}
\text { For } q<Q, & L_{1}=0 \text { and } L_{M}=L\left(K_{G}, \bar{w}, Q\right) \\
\text { For } q>Q, & L_{M}=0 \text { and } L_{1}=L\left(K_{G}, \bar{w}, q\right) \\
\text { For } q=Q, & L_{M}+L_{1}=L\left(K_{G}, \bar{w}, q\right)
\end{array}
$$

with

$$
L\left(K_{G}, \bar{w}, z\right)=\frac{K_{G}}{z+(1-z) p} \Psi\left[\bar{w} \frac{1-(1-z)(1-p) \delta}{z+(1-z) p}\right]
$$

being the labor demand for a group of workers with fraction $z$ of "high working" workers with characteristic $\theta_{L}$.

Equation (1) simply says that, given that workers are perfectly susbtituable, only workers with the lowest effective wage per unit of efficient labor units will be employed . Typically for a group with a fraction $z$ of "high working value" workers with characteristic $\theta_{L}$, the effective wage per unit of efficient labor is $\bar{w} \frac{1-(1-z)(1-p) \delta}{z+(1-z) p}$ which is a decreasing function of $z$. Hence, that group will get positive employment if and only if its proportion

\footnotetext{
${ }^{5}$ We assume as well that the minimum wage $\bar{w}$ is not too high, so that it is not profitable for any firm to hire workers at an efficiency wage that ensure that workers of type $\theta_{H}$ do not shirk (ie. $\left.\bar{w} \frac{1-(1-p) \delta}{p}<\frac{\theta_{H}}{(1-p) \delta}\right)$
} 
of "hard working" individuals is below the proportion of "high working values" workers of in the other group. The labor demand $L$ in that case will be an increasing function of the other complementary factor of production $K_{G}$ and a negative function of the wage rate $\bar{w}$.

The impact of $z \in\{q, Q\}$ on $L$ is a priori ambiguous as an increase in $z$ increases the expected number of efficient units of labor provided by workers of the group, but at the same time reduces the effective real cost of these workers $\bar{w} \frac{1-(1-z)(1-p) \delta}{z+(1-z) p}$. We make however the following assumption ensuring that the latter effect is stronger than the former :

$$
\text { Assumption 2: } \epsilon(x)=x \frac{\Psi^{\prime}(x)}{\Psi(x)}>\frac{1}{1-\delta}
$$

Thus

$$
\frac{\partial L\left(K_{G}, \bar{w}, z\right)}{\partial z}>0
$$

that is the wage elasticity of labor demand is large enough to make sure that more workers get employed when the group is known to have a larger proportion of "hard working" individuals. Further, we assume that there is always unemployment for the minority group in the "primary" labor market, that is:

Assumption 3: $L\left(K_{G}, \bar{w}, 1\right)=K_{G} \Psi[\bar{w}]<1$

\subsection{Functioning of the "ethnic labor market"}

In constrast to the primary labor market, we assume that the ethnic labor market functions under competitive conditions with no asymmetry of information and no moral hazard between ethnic entrepreneurs and their fellow workers. Production is obtained by a standard constant return to scale neoclassical production function $G\left(K_{E}, L\right)$ where $K_{E}$ is the stock of ethnic entrepreneurship. Labor demand $L_{e}$ writes as $G_{L}\left(K_{E}, L_{e}\right)=w_{e}$ where $w_{e}$ is the wage prevailing in that ethnic market.

The structure of labor market participation is then the following. We suppose that the wage rate $\bar{w}$ in the primary labor market is large enough that ethnic workers first prefer to find a job in that market rather than in their own "ethnic" pool. If they are not successful in the primary labor market, they turn next to the "ethnic labor market" and eventually get a job within their own community. For a $\theta_{L}$ worker, the participation condition to the primary labor market writes therefore as:

$$
m_{G}\left[\bar{w}-\theta_{L}\right]+\left(1-m_{G}\right) m_{e}^{L}\left[w_{e}-\theta_{L}\right] \geq m_{e}^{L}\left[w_{e}-\theta_{L}\right]
$$

or:

$$
\bar{w} \geq w_{e}
$$


where $m_{G}$ is the probability for a worker to be employed in the primary labor market and $m_{e}^{L}$ is the probability to be employed in the ethnic market. Similarly, for a $\theta_{H}$ worker, the participation condition to the primary labor market writes as:

$$
m_{G}[p+(1-p)(1-\delta)] \bar{w}+\left(1-m_{G}\right) m_{e}^{H}\left[w_{e}-\theta_{H}\right] \geq m_{e}^{H}\left[w_{e}-\theta_{H}\right]
$$

or:

$$
[p+(1-p)(1-\delta)] \bar{w} \geq w_{e}-\theta_{H}
$$

\section{- Employment probabilities and equilibrium wages :}

In the primary labor market the wage rate is $\bar{w}$ and the probabilities of employment of a worker from the ethnic group are simply:

$$
\begin{array}{lll}
q<Q & m_{G}=0 \\
q>Q & m_{G}=L\left(K_{G}, \bar{w}, q\right) \\
q=Q & m_{G} \in\left[0, L\left(K_{G}, \bar{w}, q\right)\right]
\end{array}
$$

In the sequel, except when specified, we will omit the dependence on $K_{G}$ and $\bar{w}$ and note $\left.L_{1}(q)=L\left(K_{G}, \bar{w}, q\right)\right)$. We also assume that jobs are distributed uniformely between workers of type $\theta_{L}$ and $\theta_{H}$ in that "general" market so that a residual fraction $q\left(1-m_{G}\right)$ (resp. $(1-q)\left(1-m_{G}\right)$ ) of workers of type $\theta_{L}$ (resp. $\theta_{H}$ ) remains to be potentially employed in their own "ethnic" labor market. Denote $L_{e}\left(K_{E}, w\right)$ the competitive labor demand function (ie. such that $G_{L}\left(K_{E}, L_{e}\right)=w$ ) in the "ethnic "labor market and pose $L_{L}=L_{e}\left(1, \theta_{L}\right)$ and $L_{H}=L_{e}\left(1, \theta_{H}\right)$.

It is then easy to characterize the competitive equilibrium in the ethnic labor market. This is shown in figures (1), (2) and (3). The ethnic labor demand curve $L_{e}\left(K_{E}, w\right)$ is decreasing in the wage rate in the "ethnic labor market". The supply curve $S S$ is the residual labor supply curve of workers without jobs in the "general" labor market. It is an increasing step function, reflecting simply the participation constraint of the workers" (ie. $w \geq \theta_{i}$ for $\left.i \in\{L, H\}\right)$. For $w<\theta_{L}$, no worker wants to participate in the market. For $\theta_{L} \leq w<\theta_{H}$ only the residual number $q\left(1-m_{G}\right)$ of "high working values" workers are ready to supply labor. Finally for $w \geq \theta_{H}$ all residual agents are ready to work.

We assume that the stock of ethnic entrepreneurial capital is not too large and such that there is always unemployment in the ethnic labor market.

$$
\text { Assumption 4: } K_{E}<\frac{1-L\left(K_{G}, \bar{w}, 1\right)}{L_{H}}=\frac{1-L_{1}(1)}{L_{H}}
$$

Under that condition $G_{L}\left(K_{E}, 1-L_{1}(q)\right) \leq \theta_{H}$ and therefore $K_{E}<\frac{1-L_{1}(q)}{L_{H}}$ for all values of $q$.We will consider situations in which there is unemployment in the ethnic group (ie. such that $\left.G_{L}\left(K_{E}, 1\right) \leq \theta_{H}\right)$ that is the stock of ethnic entrepreneurship cannot absorb 
all the labor force of the ethnic group. As well this means that the equilibrium wage in the ethnic labor market is such that $w^{e} \leq \theta_{H}$.

¿From this and (3) and (4), a sufficient condition to have all ethnic workers willing to participate first in the "primary" labor market is :

\section{Assumption 5: $\bar{w} \geq \theta_{H}$}

The "ethnic" labor market equilibrium can then be depicted along three possible situations, depending on where the "ethnic" labor demand curve $L_{e}\left(K_{E}, w\right)$ crosses the residual "ethnic" supply labor curve $S S$. These cases are represented in figures (1), (2) and (3).

\section{[figures 1, 2, and 3 about here]}

Formally, depending on the value of the stock of entrepreneurial capital $K_{E}$, the labor market equilibrium is described by the following conditions:

1) If $K_{E}<q\left(1-m_{G}\right) / L_{L}$, then:

$$
w_{e}=\theta_{L} ; m_{e}^{L}=\frac{K_{E} L_{L}}{q\left(1-m_{G}\right)} \text { and } m_{e}^{H}=0
$$

2) If $q\left(1-m_{G}\right) / L_{L} \leq K_{E}<q\left(1-m_{G}\right) / L_{H}$, then:

$$
w_{e}=G_{L}\left(K_{E}, q\left(1-m_{G}\right)\right) ; m_{e}^{L}=1 \text { and } m_{e}^{H}=0
$$

3) If $q\left(1-m_{G}\right) / L_{H} \leq K_{E}<\left(1-m_{G}\right) / L_{H}$, then:

$$
w_{e}=\theta_{H} \quad ; m_{e}^{L}=1 \text { and } m_{e}^{H}=\frac{K_{E} L_{H}-q\left(1-m_{G}\right)}{(1-q)\left(1-m_{G}\right)}
$$

Given that the probabilities to be employed for the two types of workers write as :

$$
m^{L}=m_{G}+\left(1-m_{G}\right) m_{e}^{L} \text { and } m^{H}=m_{G}+\left(1-m_{G}\right) m_{e}^{H}
$$

The previous discussion can be summarized by:

a) Low proportion of "high work value" workers (ie. $q<Q)$ :

$$
\begin{aligned}
& \text { if } K_{E}<\frac{q}{L_{L}} ; m^{L}=\frac{K_{E} L_{L}}{q} \text { and } m^{H}=0 \\
& \text { if } \frac{q}{L_{L}} \leq K_{E}<\frac{q}{L_{H}} ; m_{e}^{L}=1 \text { and } m^{H}=0 \\
& \text { if } \frac{q}{L_{H}} \leq K_{E} ; m_{e}^{L}=1 \text { and } m^{H}=\frac{K_{E} L_{H}-q}{1-q}
\end{aligned}
$$


b) High proportion of "high work values" workers (ie. $q>Q)$ :

$$
\begin{aligned}
- \text { if } K_{E} & <\frac{q\left(1-L_{1}(q)\right)}{L_{L}} ; m^{L}=L_{1}(q)+\frac{K_{E} L_{L}}{q} \text { and } m^{H}=L_{1}(q) \\
\text { - if } \frac{q\left(1-L_{1}(q)\right)}{L_{L}} & \leq K_{E}<\frac{q\left(1-L_{1}(q)\right)}{L_{H}} ; m^{L}=1 \text { and } m^{H}=L_{1}(q) \\
\text { if } \frac{q\left(1-L_{1}(q)\right)}{L_{H}} & \leq K_{E} ; m^{L}=1 \text { and } m^{H}=L_{1}(q)+\frac{K_{E} L_{H}-q\left(1-L_{1}(q)\right)}{1-q}
\end{aligned}
$$

c) Intermediate proportion of "high work value" workers (ie. $q=Q$ and any value $\left.m_{G} \in\left[0, L_{1}(q)\right]\right)$ :

$$
\begin{aligned}
- \text { if } K_{E} & <\frac{q\left(1-m_{G}\right)}{L_{L}} ; m^{L}=m_{G}+\frac{K_{E} L_{L}}{q} \text { and } m^{H}=m_{G} \\
\text { - if } \frac{q\left(1-m_{G}\right)}{L_{L}} & \leq K_{E}<\frac{q\left(1-m_{G}\right)}{L_{H}} ; m^{L}=1 \text { and } m^{H}=m_{G} \\
\text { if } \frac{q\left(1-m_{G}\right)}{L_{H}} & \leq K_{E} ; m^{L}=1 \text { and } m^{H}=m_{G}+\frac{K_{E} L_{H}-q\left(1-m_{G}\right)}{1-q}
\end{aligned}
$$

\subsection{Employment and cultural evolution of work values}

\section{- Cultural Evolution of work values within the ethnic community}

We wish to investigate the relationship between work status and differential work values across ethnic communities. Hence we need to endogenize the dynamics of "work values" within and across communities. To simplify matters, we will assume that the state of "work values" inside the " majority" group is exogenously given by $Q$ and invariant overtime. This allows us to concentrate our analysis on the cultural evolution of the minority group. With respect to that group, we will follow recent work the economic literature on cultural transmission (Boyd and Richerson (1985), Cavalli Sforza (1981), Bisin and Verdier (2000), (2001), (2004), Saez-Marti and Zenou (2005)) and assume that work values are culturally transmitted within the community according to an intergenerational transmission process. Consider then that the community population is stationary, with one child per parent. This size is therafter normalized to 1. A parent with an individual characteristic $\theta_{i}$ with $i \in\{L, H\}$ will transmit his trait $\theta_{i}$ to his child with some probability $P\left(\theta_{i} \mid \theta_{i}\right)$. The crucial assumption that we make here is the fact that this probability depends on his employment status $E$ for employed or $U N$ for unemployed. More precisely, we assume the following:

$$
\begin{array}{l|l}
P\left(\theta_{L}\right. & \left.\theta_{L}, E\right)=1-P\left(\theta_{H} \mid \theta_{L}, E\right)=1 \\
P\left(\theta_{L}\right. & \left.\theta_{H}, E\right)=1-P\left(\theta_{H} \mid \theta_{H}, E\right)=\gamma
\end{array}
$$




$$
\begin{array}{l|l}
P\left(\theta_{L}\right. & \left.\mid \theta_{L}, U N\right)=1-P\left(\theta_{H} \mid \theta_{L}, U N\right)=1-\beta \\
P\left(\theta_{L}\right. & \left.\mid \quad \theta_{H}, U N\right)=1-P\left(\theta_{H} \mid \theta_{H}, U N\right)=0
\end{array}
$$

with $\beta, \gamma<1$.This formulation captures the fact that the employment status of the parent affects positively the probability of transmitting the "high work values" trait while conversely, the unemployment status of the parent is more likely to transmit the "low work values" cultural trait to the child. Under such probabilities, we can easily summarize the process of cultural evolution through the following transition matrices in which the first row reflects the stage of preferences at the current generation and the first column the stage of preferences in the next generation :

$\begin{array}{ccccccc}E & \theta_{L} & \theta_{H} & & U N & \theta_{L} & \theta_{H} \\ \theta_{L} & 1 & \gamma & \text { and } & \theta_{L} & 1-\beta & 0 \\ \theta_{H} & 0 & 1-\gamma & & \theta_{H} & \beta & 1\end{array}$

Using this, the dynamics of cultural evolution of the system write as

$$
q_{t+1}=q_{t} m_{t}^{L}+q_{t}\left(1-m_{t}^{L}\right)(1-\beta)+\left(1-q_{t}\right) m_{t}^{H} \gamma
$$

According to that equation, the total number $q_{t+1}$ of "high work values" individuals inside the community in period $t+1$ is the sum of three different terms. The first term $q_{t} m_{t}^{L}$ reflects individuals with "high work values" parents employed in the primary labor market or the ethnic labor market and who transmit their trait $\theta_{L}$ with probability 1 . The second term $q_{t}\left(1-m_{t}^{L}\right)(1-\beta)$ reflects individuals with "high work values" parents who are unemployed during the period and transmit their trait $\theta_{L}$ with probability $1-\beta$. The third term $\left(1-q_{t}\right) m_{t}^{H} \gamma$ shows individuals with "low work values" parents who are employed and who transmit their trait $\theta_{H}$ with probability $\gamma$.

This equation can be rearranged as :

$$
q_{t+1}-q_{t}=-\beta q_{t}\left(1-m_{t}^{L}\right)+\left(1-q_{t}\right) m_{t}^{H} \gamma
$$

with $m_{t}^{L}$ and $m_{t}^{H}$ satisfying (5), (6) and (7).

\section{Solution of the Model}

We are now in a position to solve the dynamics of the model and determine the long run state of "work values" inside the minority group.

1) Consider first the case $q_{t}<Q$ :, using (5, we get:

$$
q_{t+1}-q_{t}=-\beta q_{t}\left(1-m_{t}^{L}\right)+\left(1-q_{t}\right) m_{t}^{H} \gamma
$$


with

$$
\begin{aligned}
& \text { if } K_{E}<\frac{q_{t}}{L_{L}} ; m_{t}^{L}=\frac{K_{E} L_{L}}{q_{t}} \text { and } m^{H}=0 \\
& \text { if } \frac{q_{t}}{L_{L}} \leq K_{E}<\frac{q_{t}}{L_{H}} ; m_{t}^{L}=1 \text { and } m_{t}^{H}=0 \\
& \text { if } \frac{q_{t}}{L_{H}} \leq K_{E} ; m_{t}^{L}=1 \text { and } m_{t}^{H}=\frac{K_{E} L_{H}-q_{t}}{1-q_{t}}
\end{aligned}
$$

It is easy to see that three possible regimes can appear in such a case:

- Proposition 1: i) If $K_{E} \leq Q / L_{L}$, then all points $q \in\left[K_{E} L_{H}, K_{E} L_{L}\right]$ are steady states. ii) If $Q / L_{L}<K_{E} \leq Q / L_{H}$, then all points $q \in\left[K_{E} L_{H}, Q[\right.$ are steady states. iii) If $Q / L_{H}<K_{E}$, then $q_{t+1}-q_{t}>0$ for all $q_{t} \in[0, Q]$ and there is no steady state in that region.

Proof: See the appendix

2) Consider now $q_{t} \geq Q$ :using (6), we get:

$$
q_{t+1}-q_{t}=-\beta q_{t}\left(1-m_{t}^{L}\right)+\left(1-q_{t}\right) m_{t}^{H} \gamma
$$

It is useful to pose the following functions:

$$
\begin{aligned}
\bar{K}_{L}(q) & =\frac{q\left(1-L_{1}(q)\right)}{L_{L}}, \bar{K}_{H}(q)=\frac{q\left(1-L_{1}(q)\right)}{L_{H}} \\
\text { and } \widetilde{K}_{L}(q) & =\frac{q\left(1-L_{1}(q)\right)}{L_{L}}-\frac{\gamma}{\beta} \frac{L_{1}(q)(1-q)}{L_{L}}
\end{aligned}
$$

Then using (6) we get immediately:

$$
\begin{aligned}
- \text { if } K_{E} & \leq \bar{K}_{L}\left(q_{t}\right) ; \quad q_{t+1}-q_{t}=\beta L_{L}\left(K_{E}-\widetilde{K}_{L}\left(q_{t}\right)\right) \\
\text { - if } \bar{K}_{L}\left(q_{t}\right) & <K_{E}<\bar{K}_{H}\left(q_{t}\right) ; \quad q_{t+1}-q_{t}=\left(1-q_{t}\right) L_{1}\left(q_{t}\right) \gamma>0 \\
\text { if } \bar{K}_{H}\left(q_{t}\right) & \leq K_{E} ; q_{t+1}-q_{t}=\left(1-q_{t}\right) \gamma L_{1}\left(q_{t}\right)+\gamma L_{H}\left[K_{E}-\bar{K}_{H}\left(q_{t}\right)\right]>0
\end{aligned}
$$

For expositional simplicity, we assume that $\bar{K}_{L}(q), \bar{K}_{L}(q)$ and $\widetilde{K}_{L}(q)$ are increasing functions of $q$ (see a sufficient condition in the appendix for this to be ensured). Then we get the following immediate result:

- Proposition 2: i) If $K_{E} \leq \widetilde{K}_{L}(Q)$, then or all values of $q_{t+1}-q_{t} \leq 0$ for all $q_{t}>Q$ and there is no steady state in that region. ii) If $\widetilde{K}_{L}(Q)<K_{E} \leq \widetilde{K}_{L}(1)$, then there is a unique steady state $\left.q^{*} \in\right] Q, 1\left[\right.$ given by $\widetilde{K}_{L}\left(q^{*}\right)=K_{E}$. iii) If $\widetilde{K}_{L}(1)<K_{E}$, then $q_{t+1}-q_{t}>0$ for all $q_{t}>Q$ and the unique steady state is $q^{*}=1$. 
Proof: See the appendix

Finally we can discuss briefly the limit case where $q_{t}=Q$ at some date. A steady state at this point $q=Q$ can only exist when the (endogenous) probability of employment in the primary labor market $m_{G}$ is such that $q_{t+1}-q_{t}=0$ at $q_{t}=Q$. Given (7), this can only be the case when $m_{t}^{L}<1$. For $m_{G} \in\left[0, L_{1}(Q)\right]$ this occurs only when we have

$$
K_{E}<\frac{Q\left(1-m_{G}\right)}{L_{L}} ; m^{L}=m_{G}+\frac{K_{E} L_{L}}{Q} \text { and } m^{H}=m_{G}
$$

In such a case the dynamics are given by

$$
q_{t+1}-q_{t}=\beta L_{L}\left(K_{E}-\widetilde{K}\left(Q, m_{G}\right)\right)
$$

with

$$
\widetilde{K}\left(Q, m_{G}\right)=\frac{Q\left(1-m_{G}\right)}{L_{L}}-\frac{\gamma}{\beta} \frac{m_{G}(1-Q)}{L_{L}}
$$

and

$$
\widetilde{K}\left(Q, m_{G}\right) \in\left[\frac{Q}{L_{L}}, \widetilde{K}_{L}(Q)\right] \text { for } m_{G} \in\left[0, L_{1}(Q)\right]
$$

It follows immediately the following conclusion

- Proposition 3: i) If $K_{E} \leq \widetilde{K}_{L}(Q)$, then $q_{t+1}-q_{t}<0$ at $q_{t}=Q$. ii) If $\widetilde{K}_{L}(Q)<$ $K_{E} \leq Q / L_{L}$, then $q^{*}=Q$ is a steady state for some value $m_{G}^{*} \in\left[0, L_{1}(Q)\right]$ such that $\widetilde{K}\left(Q, m_{G}^{*}\right)=K_{E}$. iii) If $Q / L_{L}<K_{E}$, then $q_{t+1}-q_{t}>0$ for $q_{t}=Q$.

It follows that only in the intermediate interval $\widetilde{K}_{L}(Q)<K_{E} \leq Q / L_{L}$ is the point $q=Q$ a steady state. Moreover given the dynamics described in proposition 1 for the region $q_{t}<Q$ and in proposition 2 for the region $q_{t}>Q$, this steady state is unstable.

\section{- Discussion}

Propositions 1, 2 and 3 are illustrated in figure (4),.representing the dynamics of work values in the plane $\left(q, K_{E}\right)$ as a function of the level of entrepreneurial capital $K_{E}$ in the community.

[Figure 4 about here] 
It is easy to see that when the level of entrepreneurial capital is less than some maximum value $K_{E}=Q / L_{H}$, there is always the possibility of steady states in the region. $q<Q$, in which ethnic workers have no access to the general labor market and are confined to find employment in their ethnic labor market. Indeed, in the hatched region in figure (4) (delimited by the two lines $K_{E}=q / L_{L}$ and $K_{E}=q / L_{H}$ and the vertical line $q=Q$ ), for a given value of $K_{E}$, there are multiple steady states (the whole set of points $q \in\left[K_{E} L_{H}, \operatorname{Min}\left\{K_{E} L_{L} ; Q\right\}[\right.$. These steady state are reached when the initial conditions for "work values" are low (ie. $\left.q=q_{0}<Q\right)$

These low steady states can be as well reached when initial values of $q=q_{0}$ are larger than $Q$ but when the stock of entrepreneurial capital is very low (ie. less than $\left.\widetilde{K}_{L}(Q)\right)$. In such a situation depicted by point $A$, workers initially have access to the primary labor market. However, because too many of them cannot find a job either in the general labor market or the ethnic labor market (because of the low stock of ethnic capital), the role models of "high work values" is not well culturally transmitted over generations and there cannot be a long run cultural steady state in this region. "High work values" tend on average to disappear in the group, making its members less and less attractive to jobs in the primary labor market. In the end, the cultural equilibrium is obtained in the region $q<Q$ with exclusion of the primary labor market.

If ,on the other hand the stock of entrepreneurial capital is larger than the threshold $\widetilde{K}_{L}(Q)$, there exists for all initial value $q_{0}>Q$ a long run cultural equilibrium $q^{*}$ in the region $q>Q$. This cultural equilibrium is clearly positively related to the stock of entrepreneurial capital in the ethnic group (ie. $q^{*}$ is increasing in $K_{E}$ ) and can eventually correspond to the group fully adhering to "high work values" (ie. $q^{*}=1$ ).

It is interesting to see that in this region, an increase in the ethnic entrepreneurial capital $K_{E}$ has two effects on employment of workers from that group . More precisely in such a regime ethnic employment is simply given by $L_{L} K_{E}$ while primary labor market employment is $L_{1}\left(q^{*}\right)$. Hence total employment writes as $: L=L_{L} K_{E}+L_{1}\left(q^{*}\right)$. Ceteris paribus, an increase $d K_{E}$ in $K_{E}$ has therefore the direct effect of increasing employment in the ethnic labor market by $L_{L} d K_{E}$. Given this, it has as well the indirect effect of increasing the proportion of working role models in the community, promoting therefore "hard work" values in the group. This in turn tends to favor integration in the primary

labor market. by $\frac{d L_{1}}{d q^{*}} \frac{d q^{*}}{d K_{E}}$ The full impact of an increase in the stock of ethnic entrepreneurial capital is therefore larger than its direct impact inside the community.as it generates a positive reputational externality on other ethnic workers hat can be potentially employed in the primary labor market.

\subsection{Comparative statics}

Two interesting comparative statics can be undertaken in this simple model.

Minimum wage $\bar{w}$ and labor market frictions 
First we can see how primary labor market frictions like minimum wage legislations can affect in the long run labor market integration and in the long run the dynamics of " work values". Consider for instance that the wage $\bar{w}$ in the general labor market is fixed by a minimum wage legislation.. An increase in $\bar{w}$ has the following effect on the dynamics of work values of the community. It tends to reduce the general employment level $L_{1}(q)$, whenever there is access to that market. The implications for the dynamics of "work values" is immediate. In figure (5), the curve $K_{E}=\widetilde{K}_{L}(q)$ is shifted up. For a given value of entrepreneurial capital $K_{E}$, this tends to reduce long run equilibrium "hard working" values and the capacity of the ethnic group to integrate in the labor market. in two ways. It tends to reduce the value of the cultural equilibrium. $q^{*}$ in the region $q>Q$ while it has obviously no effect on the range of possible steady states $\left[q_{H}^{*}, q_{L}^{*}\right]$ in the region with no access to the "general labor market" (ie. the region with $q<Q)$.

\section{[figure 5 about here]}

The intuition is clear. An increase in the cost of labor in the primary labor market makes firms less willing to hire workers. This in turn leads to less role models of working individuals in the group, reducing therefore the dissimination of " hard work" values. As is clear, beyond the direct impact of the labor market friction on unemployment, one has as well in the long run a further indrect negative impact on labor market participation because of the change of "work values" in the group as anticipated by employers in the general labor market. Further the preceding discussion reveals that the impact of labor market institutions goes beyond our simple example of a miminum wage. Indeed any labor market frictions that makes it more difficult for ethnic workers to penetrate the gerenal labor market, will have the same consequences on the dynamics of "work values" in the group and therefore on its capacity to integrate the economy in general.

Finally notice that across ethnic groups, those which are better endowed in ethnic entrepreneurial capital, are also less likely to be affected by such frictions. Indeed a group with a level of entrepreneurial capital as described by point $B$ in picture (6), is likely to be much more affected than a community with a level presented by point $C$. While for the better endowed group an increase in $\bar{w}$ leads simply to a reduction of " work values" from $q_{C}$ to $q_{C}^{\prime}$, for the poorly endowed community, we may get a dramatic shift from a regime with $q_{B}>Q$ to a regime with $q_{B}^{\prime}<Q$ with no more participation in the primary labor market.

[figure 6 about here] 
Change in $K_{G}$ and in general labor market conditions

It is quite obvious to see from (1) and (2) that a change in the resource stock $K_{G}$ is affecting the access to the primary labor market in the opposite direction to a change in $\bar{w}$. An increase in $K_{G}$ increases employment level $L_{1}(q)$. This in turn promotes "work values" to disseminate in the group, generating further integration in the labor market. This suggests that persistent macroeconomic conditions may well affect positively (in case of expansion) or negatively (in case of contractions) "work values" in a given social group. Similar to our previous discussion of changes in labor market institutions, it is clear that in terms of the cultural dynamics of their "work" values,.groups which are better endowed with entrepreneurial capital, are also more likely to benefit from expansionary phases and are also better sheltered from the negative side of contractionary phases.

Indeed for poorly endowed communities, we may even get some hysteresis effect for the evolution of their "work" values. Take for instance the situation described in figure 6 and a community endowed with little entrepreneurial capital $K_{E}$ and located at a steady state $A$.with general labor market participation. Then a persistent negative shock on $K_{G}$ can bring the community to a long run situation like point $B$ with its workers confined to the ethnic labor arket. If, after setting in this new equilibrium, $K_{G}$ returns to its initial value, the community will not settle back to the initial situation, As a matter of fact, it will settle in an equilibrium like $C$ where its members are still excluded from the primary labor market. This discussion suggests that persistent (but not permanent) changes in the economic environment may still have permanent effects on social values of groups, especially for those which do not benefit from an active intra-group labor market.

\section{Endogenous entrepreneurial capital}

So far we treated the level of ethnic entrepreneurial capital as exogenous. In reality, this variable is likely to be itself endogenous to the pattern of cultural values devoted to work in the community. Indeed, one may expect that it is more profitable to invest in a market with a high proportion of "hard working" workers than in a market where the average population is naturally less inclined to make efforts on the job. If that happens, then certainly our variable $K_{E}$ will depend on $q$. In order to see that in the simplest way let us consider that in each period there is a capital market on which ethnic firms can raise and invest capital for production inside their community.at a capital cost $\bar{r}$ One may then compute the $r_{E}$ return of such an investment, depending on the "pool" of workers they have access to in their community. As usual two cases can be discussed depending on the participation of ethnic workers into the primary labor market.

1) Low "work values" in the community (ie. $q<Q$ ). We have then the following:

- if $K_{E}<q / L_{L}$, we have $w_{e}=\theta_{L}$, ethnic employment is $K_{E} L_{L}$ and the return of 
"ethnic entrepreneurial capital is given by:

$$
r_{E}=\frac{G\left(K_{E}, K_{E} L_{L}\right)-\theta_{L} K_{E} L_{L}}{K_{E}}=G\left(1, L_{L}\right)-\theta_{L} L_{L}=r_{L}
$$

- if $q / L_{L} \leq K_{E}<q / L_{H}$, then $w_{e}=G_{L}\left(K_{E}, q\right)$, employment is $q$ and:

$$
r_{E}=\frac{G\left(K_{E}, q\right)-G_{L}\left(K_{E}, q\right) q}{K_{E}}=G\left(1, \frac{q}{K_{E}}\right)-G_{L}\left(1, \frac{q}{K_{E}}\right) \frac{q}{K_{E}}=r\left(\frac{q}{K_{E}}\right)
$$

with $r($.$) an increasing function.such that r\left(L_{L}\right)=r_{L}$

- if $q / L_{H} \leq K_{E}$, then $w_{e}=\theta_{H}$, ethnic employment is $K_{E} L_{H}$ and:

$$
r_{E}=\frac{G\left(K_{E}, K_{E} L_{H}\right)-\theta_{H} K_{E} L_{H}}{K_{E}}=G\left(1, L_{L}\right)-\theta_{H} L_{L}=r_{H}
$$

notice as well that $r\left(L_{H}\right)=r_{H}$

The ethnic capital return function is plotted in figure (7). In order to focus on the case with an interior solution for the stock of capital $K_{E}$ which is also compatible with ethnic unemployment, we assume:

$$
\text { Assumption 6: } \bar{r} \in] r_{L}, r_{H}[
$$

Then the ethnic entrepreneurial capital level is given by $r\left(q / K_{E}\right)=\bar{r}$ or noting $\frac{1}{r^{-1}(\bar{r})}=\lambda(\bar{r})$

$$
K_{E}=K_{E}(q)=\lambda(\bar{r}) q
$$

with $\lambda(\bar{r})$ a decreasing function of $\bar{r}$. Moreover given assumption 6 , we know that $q / L_{L} \leq$ $K_{E}^{*}(q)<q / L_{H}$

2) High "work values" in the community (ie.q $>Q$ ). Then we get the following:

- If $K_{E} \leq \bar{K}_{L}(q)$ then $w_{e}=\theta_{L}$, ethnic employment is $K_{E} L_{L}$ and $r_{E}=r_{L}$

- If $\bar{K}_{L}(q)<K_{E}<\bar{K}_{H}(q)$ then $w_{e}=G_{L}\left(K_{E}, q\left(1-L_{1}(q)\right)\right.$, ethnic employment is $q\left(1-L_{1}(q)\right)$ and

$$
r_{E}=r\left[\frac{q\left(1-L_{1}(q)\right)}{K_{E}}\right]
$$

- If $\bar{K}_{H}(q)<K_{E}$ then $w_{e}=\theta_{H}$, ethnic employment is $K_{E} L_{H}$ and $r_{E}=r_{H}$

Again it is worth noting that at the level $\bar{K}_{L}(q)$ (respectively $\bar{K}_{H}(q)$ ), we have $r_{E}=r_{L}$ (respectively $r_{E}=r_{H}$ ). It follows that the entrepreneurial capital level is given by :

$$
K_{E}=K_{E}(q)=\lambda(\bar{r}) q\left(1-L_{1}(q)\right)
$$

Moreover given our assumption 6 , we know that for that $\bar{K}_{L}(q)<K_{E}(q)<\bar{K}_{H}(q)$ 
[Figure 7 about here]

¿From the previous discussion, figure (4) is modified as shown in figure (7). Indeed for the region $q<Q$ there is now a new line $K_{E}=\lambda(\bar{r}) q$ that is in-between the two rays $q / L_{L}$ and $q / L_{H}$, showing the amount of entrepreneurial capital compatible with a given cultural steady state $q$. In the region $q>Q$, there is as well the new curve $K_{E}=\lambda(\bar{r}) q\left(1-L_{1}(q)\right)$ which is necessarily above $K_{E}=\bar{K}_{L}(q)$. This implies that in this region the only steady state is $q^{*}=1$ with the whole social group adopting "high work values" This discussion is summarized in the following proposition:

- Proposition 4: Assume that assumption (6) holds, then we have:

i) If $q_{0}<Q$, then $q_{0}$ is a cultural steady state and the level of entrepreneurial capital is $K_{E}=\lambda(\bar{r}) q_{0}$

ii) If $q_{0}>Q$, then the cultural steady state is $q^{*}=1$, associated in the long run with a level of entrepreneurial capital $K_{E}=\lambda(\bar{r})\left(1-L_{1}(1)\right)$

Proposition 4 illustrates in a extreme form the complementarity between the cultural evolution of "work values" and the pattern of investment in ethnic entrepreneurial capital. Assuming that ethnic entrepreneurs have free access to the capital market to make their investment, we see from ii) that once "work values" are sufficiently disseminated in the group (ie. $q_{0}>Q$ ), this stimulates investment in ethnic entrepreneurial capital. This investment leads in turn to better labor market integration. Via the pattern of role models it stimulates, this further promotes the diffusion of "work values" in the group. In this simple framework, the whole effect of this process is complete assimilation of the "high working" values in the community and a high level of ethnic entrepreneurial capital.

Obviously, if ethnic investors are constrained on the credit market, there is a ceiling $\bar{K}_{E}$ such that $K_{E} \leq \bar{K}_{E}$. When the ceiling is binding, the dynamics of "work values" in the group will evolve according to the model with an exogenous level of entrepreneurial capital $\bar{K}_{E}$. If that level is less than $\widetilde{K}_{L}(1)$, then we get the same long run results as in proposition 2 for initial conditions $q_{0}>Q$ and the group can stay less than fully socialized to "hard work values" (ie. $q^{*}<1$ )

\section{Empirical evidence in the case of France}

Long term unemployment, precarity and exclusion from the labour market constitute a major issue in France. It has progressively become a widespread view that the French labour market is a segmented one (ref: blanchard, cahuc?); moreover, the evidence seems to be that the nationality and foreign origin of individuals is not neutral with respect to their situation on this segmented market. 
Quantitatively, the latest available census (1999) reports a population of 58,5 millions inhabitants, of which 5,6 millions immigrants (i.e. people born in a foreign country with a foreign nationality), including 1,67 millions immigrants from Maghreb (Algeria, Morocco, Tunisia), and 1,79 millions immigrants from Southern Europe (Italy, Spain, Portugal). These two groups constitute the most important minorities in France; they account for $62 \%$ of foreign immigrants. However, these figures only account for immigrants of the first generation. According to the survey that we use (Histoire de Vie, INSEE, 2003), immigrants of the first and second generation represent up to $16.6 \%$ of the population, count about 8\% from Maghreb and 5\% from Southern Europe.

In this section, we provide an illustration of the influence of entrepreneurship on cultural work attitudes and labour market integration of these two main ethnic minorities in France. We mainly hinge on a survey of the French population ("Histoire de vie", INSEE 2003), in which immigrants of the first and second generations were deliberately over-represented, and which contains a series of subjective attitudinal questions regarding work values.

We first some present descriptive statistics documenting the specificity of the professional integration of North African versus Southern European immigrants, insisting on their sector specialisation and their social network. We then propose an econometric test of the role of the social "entrepreneurial" network of immigrants. Matching the "Histoire de vie" survey with the French population census of 1999, we device an identification strategy based on the regional variability of the entrepreneurial social capital of ethnic minorities in France. We first observe that the work values of the North African immigrants are significantly different from those of other segments of the population; however, we show that this specificity is statistically totally explained by the entrepreneurial network of this group. These findings are consistent with a model of cultural transmission of work values through the density of entrepreneurial capital available to the members of each group of immigrants.

\subsection{Data}

This section mainly hinges on a survey of the French population, Histoire de vie construction des identités, conducted in 2003 by the national statistical office (INSEE) with many other institutional partners. The sample of the survey includes 8403 adults living in France (metropolitan), with a deliberate over-representation of the foreign and immigrated population. About half of the sampled population was professionally active in 2003 (4 387 persons).

The survey contains both objective and subjective information about individuals' trajectories since their birth. After a general, broad-ranging questioning, respondents were asked about their attitude towards work. The first question deals with the place of work in the identity of respondents: "Among the topics that we have been talking 
about, which are the three items that most fit with you, that best describe who you are? (job, family, leisure, origins, language, etc.)". Professionally active respondents were also asked to evaluate the relative importance of work in their life, compared to other aspects of their life: "nowadays, would you say that in your life in general your job; 1 . is more important than all the rest; 2 . is very important but at pair with other things (family, personal life, social life, etc.); 3. is important but less than other things; 4 . is not very important". Finally, professionally active respondents were asked whether, in their job, satisfaction motives outweigh dissatisfaction motives. (See the Annex for the complete wording of these questions).

In spite of the specific composition of the sample, foreign respondents are not numerous enough to allow for a distinction amongst the different generations of immigrants. We thus define a broad notion of "origin" based on the information available for the respondents and their parents (two generations) concerning their country of birth and nationality at birth. Firstly, we define a category of people "of North African origin", which includes all individuals whose nationality at birth, or that of at least one of their parents, was either Algerian, Moroccan or Tunisian, or whose birth place, or that of at least one of their parents, is located in this region. We also use the mother tongue declared by the respondents as a double check (Tribalat 2004). We proceed in the same way for the definition of the group of people with a "Southern European origin" (Italy, Spain and Portugal). Thirdly, we isolate native French people who were born French and whose two parents were born in France with a French nationality- admittedly a very restrictive definition. The last group is the residual (immigrant of the first or second generation, not coming from Southern Europe or Maghreb).

Because we are interested in the professional integration of these groups, we only retain the sub-sample of males, aged from 18 to 60 years old. This is needed to avoid the specific situation of senior people on the French labour market (Hairault et al., 2006, 2007), as well as the influence of different cultural attitudes regarding children care and female participation in the labour market (Fernandez and Fogli 2007, Guiso and al., 2006).

This grouping reveals important differences, both objective and subjective, in terms of integration into the labour market.

\subsection{Work Attitudes and Discrimination on the French Labour Market}

Simple descriptive statistics (Table 1) suggest that immigrants from North Africa attach less importance to their job than other segments of the population; they consider their job as a more minor motive of identity and are less satisfied with it. By contrast, people coming from Southern Europe are closer, in their declared attitudes, to the native French and declare more frequently that working is at least as important as other aspects of life 
(column 4, table 1). As shown by Table 2, this difference holds even when one controls for the classical socio-demographic circumstances.

[Table 1] about here

Of course, the subjective work attitudes of people of North African origin is related to their objective working conditions: they are more often unemployed, less often on a permanent contract, and suffer generally from less stability in their working conditions.

An important literature has illustrated racial discrimination on the American labour market (see Altonj et Blanck, 1999, Neal et Johnson, 1996). In France, the common knowledge is that immigrants suffer from a more difficult access to employment rather than from lower wages (Joseph and Lemière, 2005). However, beyond this observation, surveys have also documented the existence of an important heterogeneity among immigrants: people of North African origin are more often unemployed and experience a more discontinuous career, in sharp contrast with the situation of workers of South European origin (Dayan et al., 1996 ; Dos Santos, 2005; Maurin, 1991 ; Meurs et al., 1999 ;Okba and Lainé, 2004 ; Tribalat, 2004, 2005; Silberman and Fournier, 2007).

The nationally representative survey Histoire de Vie confirms these observations. Among male respondents aged 18 to 60 years old, immigrants from North Africa are twice as often unemployed (14\%) as other workers; their rate of activity (59\%) is 20 points lower than the national average (Table 2). The proportion of workers of Maghrebian origin that hold a permanent contract $(77 \%)$ is ten points lower than the average. They more often than others occupy low skill jobs (Table 3). Eventually, their labour income is lower: about half of them have an income below the median income, as opposed to $31 \%$ of the average active men aged 18 to 60 years in the general population. All these observations hold in a regression with controls for the productive and socio-demographic circumstances of individuals (Table 4).

[Table 2, 3, 4 about here]

Stylized facts established by the literature complete this picture (Caille, 2005; Dos Santos, 2005; Lainé and Okba, 2004, 2005; Joseph and Lemière, 2005; Meurs et al. forthcoming; Silberman and Fournier, 2006, 2007; Tribalat, 2004, 2005). In terms of education, students of North African origin often choose general instead of professional education tracks, as opposed to the more technical and professional tracks chosen by South European students. Moreover, the education fields chosen by the young Portuguese, for instance, are consistent with the job opportunities offered by employers of the same origin, namely a network of small and medium size firms concentrated in a few industrial 
sectors such as house-building and public construction, or qualified manual occupations in the sectors of electricity, electronics, graphic industries and automobile reparation, which can be thought of as a sort of "ethnic labour market". By contrast, young workers of Maghrebian origin cannot rely on the same type of integration network. Their fathers are more often unqualified workers employed in restructuring sectors or unemployed, hence unable to give them access to employment. They are more often concentrated in larger and public firms where they have less control over the hiring process. There are also fewer independent workers among the immigrants from Maghreb. Young people of North African origin more often occupy jobs in the service sector, especially low qualification jobs (cleaning, care-taking, security guards, transportation), or jobs in the public and social sector (public hospitals, public housing, local municipalities); they also occupy low-skill blue-collar jobs (handling process, machine-building).

The survey "Histoire de Vie" also contains questions relating to the social life of respondents. It shows that respondents of North African origin less often meet their colleagues outside work ( $27 \%$ of them do, as compared to $36 \%$ in average). Among their friends, the ratio of people exerting the same profession $(26 \%)$ is much lower than the average (37\%); whereas they more often make friends with people with the same geographical origin (36\% versus $30 \%$ in average). They also participate less in professional organisations (4\% versus $10 \%$ for French and $7 \%$ for other immigrants). Hence, the professional component of the social capital of the first and second generations of immigrants from North Africa seems to be particularly weak.

Concerning the transmission of work attitudes, the survey "Histoire de vie" reveals that $8 \%$ of respondents of North African origin declare that they have not seen their father work (because he was absent, retired or unemployed) when they were aged 15 years old, against $4 \%$ in average. De facto, controlling for the usual observable characteristics (age, matrimonial status, number of children, education, region), the fact of having an absent or unemployed father (hence no working model) significantly increases the probability of being inactive for men aged 18 to 60 years (see infra).

In a nutshell, the picture that is suggested by the literature and that seems to be supported by the survey "Histoire de vie" is the following: Immigrants from Maghreb, employed in large industrial firms, mostly in unqualified occupations, were particularly exposed to the shock of recession and industrial restructuring in the 1970's; moreover they lacked the network of social relations that could have allowed them to escape unemployment and inactivity. The subsequent generations have not benefited from a network of "ethnic" firms that could naturally integrate them. This contrasts with the situation of immigrants from Southern Europe, who were protected fro long term unemployment thanks to a network of entrepreneurs concentrated in a few sectors. A study by Dos Santos (2005) reveals that about $60 \%$ of Portuguese workers declare that they have found their job using personal relations or thanks to persons of the same origin; this difference persists even in a regression with the usual controls. 
These stylized facts are consistent with a model of inter-generational transmission of work attitudes, where social capital plays both a direct role in the access to job and an indirect role in the transmission of work values. Moreover, this dynamics can be self-reinforcing as it becomes common knowledge and is integrated in the expectations of employers.

\subsection{The role of entrepreneurial network in the transmission of work values and access to employment}

We now propose a more rigourous test of the role of the entrepreneurial network on the transmission of work values in France. Our identification strategy relies on the regional variability of the density of ethnic networks. To this end, we match the survey "Histoire de vie" with the 1999 French census, which contains the number employers of each geographical origin for each of the 22 French regions (surveyed people self-declare their occupation amongst the following categories: inactive/employee/independent/employer).

Our objective is to put in evidence the influence of the regional density of employers of a given origin on the probability of being active, and on the work values of the individuals of the same origin. If I am a worker of North African origin, are my work values and my chance to be employed influenced by my "ethnic" professional network?

Clearly, one cannot answer this question by running a simple regression of individual work values on the national proportion of entrepreneurs in her ethnic group. Indeed, the latter is collinear with the dummy variable representing the ethnic group itself, so that in fine, this naive estimation would only capture the influence of one's origin on her work values, which would be circular. To overcome this problem, we use the French census to compute the share of entrepreneurs of each ethnic group among the total number of entrepreneurs of each region. Let $E^{j}$ be the number of employers in region $j$, and $E_{k}^{j}$ the number of entrepreneurs of ethnic group $k$ in region $j$; $\mathbf{E} k i$ is the vector containing the ratio $E_{k}^{j} / E^{j}$ for each individual $i$ living in region $j$ and belonging in the ethnic group $k$.

We regress the work values of individual $i$ living in region $j$ and belonging in ethnic group $k$ on a dummy for her ethnic group and the ratio $\mathrm{E}_{k j}=E_{k}^{j} / E^{j}$, controlling for her other professional and socio-demographic controls $\mathbf{X}_{i}$.

$$
\text { WorkValues }_{i}=a_{0}+a_{1} \text { ethnicgroup }_{k}+a_{2} \mathbf{E} k i+a_{3} \mathbf{X}_{i}+u_{i}
$$

where $u_{i}$ is the error term, $k=$ native French, or immigrant from Maghreb, Southern Europe or Else and $j=1,22$. Because $E_{k j}$ is defined at the regional level, we calculate robust standard errors by clustering at the regional level.

Thanks to the regional variance of the ratio $E_{k j}$, if the latter turns out to be statistically significant, it will not be the mere reflect of other characteristics of the ethnic groups $E_{k j}$. 
The main identifying assumption of equation (9) is that $E_{k j}$ is uncorrelated with the error term $u_{i}$. This implies, in particular, that there has not been an allocation of immigrant workers with higher work values to regions with a higher concentration in ethnic entrepreneurs. The well-documented low regional mobility of workers on the French labour market (e.g. Pumain and Courgeau, 1993, Gaymard, 2005) comforts this assumption. However, one could suspect that immigrants from Maghreb, and in particular entrepreneurs, have chosen to localise in regions that were less hostile to their ethnic group. However, the share of self-declared discriminated persons is very weakly correlated with the share of immigrants from Maghreb in the regional population. By contrast, the coefficient of correlation between the share of immigrants from North Africa amongst the local employers and the average feeling of discrimination of this group is high: 0,31 . The presence of entrepreneurs thus does not seem to reflect the lesser hostility of the local population.

The identification of equation (9) is also threatened by the risk that an omitted variable could be correlated both with the number of employers of a given origin in the region (in 1999) and the work values of workers of the same origin (in 2003). For example, one could argue that the average regional wealth of the ethnic groups influences both the number of employers in this group (because it takes money to be an entrepreneur) and the work values of the group (through education, social relations, etc.). Although we cannot completely discard this alternative explanation, available studies on this issue show that financial capital is not the only condition for becoming an entrepreneur; the family role models are at least as important (Blanchflower and Oswald, 1998, Laferrere, 2001). It would thus be exaggerated to reduce the role of the ethnic network of entrepreneurs to the capital generated by this activity.

Finally, an interpretation of the results in terms of reverse causation would imply that the share of employers of North African origin in region j in 1999 is influenced by the work values of the inhabitants of the region in 2003. Literally, this is obviously farfetched; however, it is possible that work values were already different in 1999 and have influenced the regional allocation of entrepreneurial capital. However, we do not need to exclude this interpretation which is compatible with the logic of the model, where in the long run equilibrium, work values, ethnic entrepreneurial capital and labour market integration are closely interdependent.

\subsubsection{Results}

We start by introducing dummies representing the geographical origin of respondents in the regression of work attitudes (columns 1, 3, 5, 7 in Table 5). The dummy for North African origin appears to exert a significantly negative impact on the work values of respondents. Immigrants of this origin are more often dissatisfied with their job, less often declare that work is an important aspect of their life, less often quote their job as an major motive of identity and have a higher probability to be inactive. 


\section{[Table 5 about here]}

We then introduce the ratio $E_{k j}$ in the same regressions (columns $2,4,6,8$ ). Table 5 shows that this ratio completely neutralizes the influence of ethnic dummies. More precisely, the dummy for North African origin, which is highly significant in the regression of work values, loses all its explanatory power once the ratio $E_{k j}$ is introduced. This is true for job identity, for job dissatisfaction, and for the probability of being active. Concerning the importance attached to one's job, the effect is even more spectacular as the sign of the coefficient is reversed after the introduction of this ratio! Hence, once the effect of the ethnic networks is taken into account, it appears that the importance of work is greater for workers of North African origin than for French natives (the reference category). For all the other variables, job as a motive of identity, job satisfaction or the probability to be inactive, there is no significant difference left after the regional share of ethnic entrepreneurs is taken into account.

As explained earlier, a well-known stylized fact of the French labour market is the contrast between the situation of the minority of immigrants from North African and the South European group. Table 4 confirms this prior. It shows that, before the introduction of the ratio $E_{k j}$, belonging to the group of South European immigrants does not imply different work attitudes as compared to the average French natives. The coefficients on the work values of this group are not significant. Hence, at first sight, the work values of the male immigrants from Southern Europe are close to the French ones (which constitute the category of reference). The only difference is the lower probability of South European immigrants of being inactive. Then, introducing the ratio of ethnic entrepreneurs kills the effect of the ethnic dummy on the probability to be inactive, but surprisingly has the opposite effect of rendering the coefficient significant and positive as concerns certain work values: job satisfaction and the importance of work.

This set of results suggests that, conditional on the integration network available to them, immigrants from Southern Europe are both more attached to work and more satisfied with their job than the average native French workers. In the case of immigrants from North Africa, once the effect of their network of employers taken into account, it appears that their work values and probability to be inactive are the same as those of the French natives, with the exception of the higher importance that they attach to work (as compared to other activities).

In summary, the work attitudes of the ethnic minorities in France seem to be, to a large extent, determined by the availability of their ethnic network. However, beyond this effect, the importance of work (as compared to other aspects of life) proves to be more important to these immigrants than to the French natives, a feature that was not apparent in naïve descriptive statistics. It is indeed noticeable that, contrarily to what is suggested by the raw statistics of Table 1, once the influence of the social network neutralized, it appears that the importance of work is more important for immigrants, including North-African immigrants of the first and second generation, than for the 
native French. This finding is consistent with the fact that immigration is most often based on economic motives.

The last two regressions presented in table 4 investigate the determinants of labor market integration. They include, as a control, a dummy variable representing whether respondents declare that their father was absent or unemployed when they were aged 15 . This dummy has a significant impact on the probability to be inactive. Again, comparing regressions 7 and 8, the North African dummy looses significance, after controling for the ratio of employers of the same origin in the region ${ }^{6}$.

Overall these results suggest that work values, social networks and labour market participation are highly correlated. More generally, rather than relations of causality, the results should be taken as indicating correlations between the observed variables. This is consistent with our theoretical model, which suggests that in the long run, those variables are strongly interdependent. The main claim of the paper is not so much about the causality running from entrepreneurship to work values, but rather about the possibility that different equilibria can occur, in which work values, entrepreneurship and labour market integration are closely intertwined. This rules out the idea that cultural factors constitute the ultimate explanation for the labour market situation of certain minorities.

\section{Conclusion}

The data of this new French survey seem to comfort the interpretation of the French labour market as a segmented market in which the geographical origin of workers matters. A first naïve look at the raw data sketches the particular situation of the minority of North African origin. Immigrants from this region are particularly poorly integrated in the labour market; they experience higher rates of unemployment and more instability; they also seem to attach less importance to their job, to consider their job as a more minor motive of identity and to be less satisfied with it. These stylized facts concerning the objective working conditions and the subjective work values of immigrants from Maghreb immediately point to two possible explanations: discrimination and cultural factors.

This paper shows that the story is more complex. Once the social capital specific to each group of immigrants is taken into account, the specificity of immigrants from North Africa in terms of work values becomes statistically insignificant or may be actually reversed. For instance, concerning the subjective statement that "work is important as

\footnotetext{
${ }^{6}$ Note that the results of Table 6 are essentially unchanged when we drop this control from the regressions. We also verified that the work values that are explained in Table 5 in columns 5 to 6, i.e. the place of work in people's identity are themselves important determinants of the probability to be inactive (coefficient on job identity -1.099 [0,123], logit regression, 2908 observations, Log likelihood=1052, Pseudo R2=0.24)
} 
compared to other aspects of life", it appears that immigrants, including the minority from North Africa, attach more importance to work than French natives, once the effect of "ethnic" social capital is controlled for.

These findings suggest that ethnic social capital plays an important role in shaping people's attitude towards work, and that entrepreneurial capital is a key element of social capital. Labour market segmentation, entrepreneurship and work values are closely intertwined and, under similar global economic conditions, may define various possible long run stable equilibria across minority groups.

These effects do not constitute a substitute explanation to ethnic discrimination; rather they must be seen as complementary. Indeed, network effects potentially reinforce (or reduce) the stigma attached to each minority, depending on its records in terms of labour market integration. Hence, the policy recommendation that would be consistent with the view supported by this paper is not to minimize the importance of discrimination, but to suggest an additional entry for public policy. While it may be difficult to directly affect work values at a given point in time, our analysis suggests that policies promoting labor market integration and/or entrepreneurial investment in discriminated minority groups, may in the long run have snowball effects in terms of dynamics of socialization and evolution of work values of the younger generations of these groups. This, in turn will facilitate further labor market participation and entrepreneurship within these groups. Finally, by improving their socio-economic integration, this may also contribute to the reduction of discrimination against these groups. 


\section{Bibliography}

Aldrich H, Cater J., Jones T., and Mc Evoy D.(1981), "Business Development and Self-Segregation: Asian Enterprise in Three Bristish Cities, In Peach C., Robinson V., and Smith S., (Eds). Ethnic Segregation in Cities, Croom Helm, London.

Altonj J. and Blank R., Race and gender in the Labor Market, Chapter 48, Handbook of Labor Economics, volume 3, 1999.

Barrett G.A., Jones T.P., and Mc Evoy D., (1996), "Ethnic Minority Business: Theoretical Discourse in Britain and North America, Urban Studies, vol. 33 ,4-5, pp. 783-809.

Blanchflower, D.G,. \& Oswald, A.J., 1998, "What Makes an Entrepreneur?". Journal of Labor Economics, 16, 26-60.

Bisin, A. and T. Verdier (2000), "Beyond the Melting Pot: Cultural Transmission, Marriage, and the Evolution of Ethnic and Religious Traits," Quarterly Journal of Economics 115, 955-988.

Bisin, A. and T. Verdier (2001), "The Economics of Cultural Transmission and the Dynamics of Preferences," Journal of Economic Theory 97, 298-319.

Borjas G. (1992) "Ethnic Capital and Intergenerational Mobility," Quarterly Journal of Economics, February, pp. 123-150.

Borjas G. (1995) "Ethnicity, Neighborhoods, and Human-Capital Externalities," American Economic Review, June, pp. 365-390

Boyd, R. and P. J. Richerson (1985), Culture and the Evolutionary Process, Chicago: University of Chicago Press.

Cavalli-Sforza,L.L., and M. W. Feldman (1981), Cultural Transmission and Evolution. Princeton: Princeton University Press.

Dayan J.-L., Echardour A., Glaude M., 1996, "Le parcours professionnel des immigrés en France : une analyse longitudinale", Economie et Statistique, n²99, 107-127.

Dupray A. and Moullet S., 2005, Quelles discriminations à l'encontre des jeunes d'origine maghrébine à l'entrée sur le marché du travail en France? , colloque DARESINED L'insertion scolaire et professionnelle des jeunes issus de l'immigration mars 2005

Dos Santos M., 2005, "Travailleurs maghrébins et portugais en France : Le poids de l'origine", Revue Economique, 2005, volume 56, pages 447-464.

European Social Survey: http://www.europeansocialsurvey.org.

Fernandez R. and Fogli A., 2007, "Women, Work, and Culture , Journal of the European Economic Association, forthcoming.

Fitoussi J-P., Laurent E. and Maurice J., 2004, Ségrégation urbaine et intégration sociale, Conseil d'Analyse Economique, la Documentation Française.

Frickey A. and Primon J-L, 2002, Jeunes issus de l'immigration : les diplômes de l'enseignement supérieur ne garantissent pas un égal accès au travail , Formation-Emploi, $\mathrm{n}^{\circ} 79$.

Gaymard M., "Les territoires d'accueil des étrangers en France de 1946 à 1999", in Bergouignan C., Blayo C., Sardon J-P and Tribalat M. eds, La population française, 
CUDEP, Université Bordeau IV, pp 649-671.

Glaude M. and C. Borrel (2002) : Les immigrés et leurs descendants sur le marché du travail : un regard statistique in Immigration, marché du travail, intégration, Commissariat Général du Plan, La Documentation française.

Hairault J-O, 2006, The Interaction between Retirement and Job Search: A Global Approach to Older Workers’ Employment”, IZA DP n¹984.

Hairault J-O, 2006, "Job Creation and Job Destruction over the Life Cycle: The Older Workers in the Spotlight", IZA DP n²597.

Joseph O. and Lemière S., La discrimination de genre et d'origine à l'encontre des jeunes sur le marché du travail , CEREQ, Net.Doc.12, mars 2005.

Knocke W., (2000), "Integration or segregation? Immigrant Populations Facing Labour Market in Sweden, Economics and Industrial Demography, vol. 21, 3, pp. 361-380.

Laferrere A., 2001, "Self-employment and Intergenerational Transfers: Liquidity Constraints and Family Environment", International Journal of Sociology, 31 (1).

Lainé Frederic and Okba Mahrez, 2005, Scolarisation et diplômes obtenus en fin de scolarité des jeunes issus de l'immigration, colloque DARES-INED L'insertion scolaire et professionnelle des jeunes issus de l'immigration mars 2005.

Meurs D., Pailhé A. and Simon P., Immigrés et enfants d'immigrés sur le marché du travail : une affaire de génération ? , Population, forthcoming.

Neal D. and Johnson W., 1996, The Role of Pre-Market Factors in Black-White Wage Differences , Journal of Political Economy, 104 (5), 869-895.

Okba M.and Lainé F., 2004, L'insertion des jeunes issus de l'immigration : métiers occupés, trajectoires scolaires et professionnelles, Actes du colloque du Cerc, Le devenir des enfants de familles défavorisées en France, avril 2004.

Phelps E., 1972 The Statistical Theory of Racism and Sexism , American Economic Review, 62(4).

Portes A., and Bach R., (1985), Latin Journey: Cuban and Mexican Immigrants in the United States, Berkeley: University of California.

Portes A., and Manning R.D., (1986), "The Immigrant Enclave, Theory and Empirical Examples", in Competitive Ethnic Relations, S.Olzak and J. nagel (Eds) , New York Academic Press.

Portes A. and Sensenbrenner J., 1993, Embededness and Immigration : Notes on the Social Determinants of Economic Action , American Journal of Sociology, 98(6), 1320-1350.

Putnam R. (2007) "E Pluribus Unum: Diversity and Community in the Twenty First Century; The 2006 Johan Skytte Prize Lecture". Scandinavian Political Studies, 30, 137-174.

Ram M., and T.,Jones (1998), Ethnic Minority, Small Business Research Trust, Milton Keynes, UK. 
Saez-Marti, M. and Y. Zenou (2005), "Cultural Transmission and Discrimination" Unpublished Manuscript, Research Institute of Industrial Economics, Stockholm.

Silberman R., Alba R., Fournier I., 2007, "Segmented assimilation in France? Discrimination in the labour market against the second generation", Ethnic and Racial studies, Vol. 30, $\mathrm{n}^{\circ}$ 1, p. 1-27.

Silberman R., Fournier I., 2006, "Les secondes générations sur le marché du travail en France : une pénalité ethnique ancrée dans le temps. Contribution à la théorie de l'assimilation segmentée", Revue française de sociologie, Vol. 47, n 2, p. 243-292.

Stiglitz J., 1973, Approaches to the Economics of Discrimination , American Economic Review, 63(2), 287-295.

Tribalat M., (2004), "An estimation of the foreign-origin populations of France in 1999", Population, 59(1), 49-80.

Tribalat M., (2005), "Situation sociale des enfants nés en France de parents immigrés", in Bergouignan C., Blayo C., Sardon J-P and Tribalat M. eds, La population française, CUDEP, Université Bordeau IV, pp 685-711.

Tribalat M., (2005), "Une estimation des populations d'origine étrangère en 1999", in Bergouignan C., Blayo C., Sardon J-P and Tribalat M. eds, La population française, CUDEP, Université Bordeau IV, pp 671-684.

Waldinger R., (1993), "The Ethnic Enclave Debate Revisited", International Journal of Urban and Regional Research, 17, pp. 444-452.

Weil P., 2005, La République et sa diversité. Immigration, Intégration, Discrimination, Seuil, coll. La République des Idées.

Wilson K.L., and Portes A., (1980), "Immigrant Enclaves: An Analysis of the Labour Experience of Cuban in Miami", American Journal of Sociology, 89, pp. 295-208. 


\section{Appendix}

Proof of proposition 1: It is easy to see that

$$
\begin{aligned}
\text { if } q_{t} & \leq K_{E} L_{H} ; & q_{t+1}-q_{t}=\left(K_{E} L_{H}-q_{t}\right) \gamma>0 \\
\text { if } K_{E} L_{H} & <q_{t} \leq K_{E} L_{L} ; & q_{t+1}-q_{t}=0 \\
\text { if } K_{E} L_{L} & <q_{t} ; & q_{t+1}-q_{t}=-\beta\left(q_{t}-K_{E} L_{L}\right)<0
\end{aligned}
$$

Hence

i) When $K_{E} \leq Q / L_{L}$, for $q_{t}<Q$, the dynamics are described by (10) and it follows immediately that the set $\left[K_{E} L_{H}, K_{E} L_{L}\right]$ describes the set of stable steady states.

ii) When $Q / L_{L}<K_{E} \leq Q / L_{H}$, then for $q_{t}<Q$, we necessarily have $q_{t} \leq K_{E} L_{L}$ and the dynamics of the system writes as:

$$
\begin{aligned}
\text { if } q_{t} & \leq K_{E} L_{H} ; \quad q_{t+1}-q_{t}=\left(K_{E} L_{H}-q_{t}\right) \gamma>0 \\
\text { if } K_{E} L_{H} & <q_{t}<Q ; \quad q_{t+1}-q_{t}=0
\end{aligned}
$$

and the set $\left[K_{E} L_{H}, Q[\right.$ are steady states.

iii) Finally when $Q / L_{H}<K_{E}$, then for $q_{t}<Q$, we necessarily have $q_{t} \leq K_{E} L_{H}$ and the dynamics of the system writes as:

$$
\text { if } q_{t} \leq K_{E} L_{H} ; \quad q_{t+1}-q_{t}=\left(K_{E} L_{H}-q_{t}\right) \gamma>0
$$

Thus the result. $q_{t+1}-q_{t}>0$ for all $q_{t} \in[0, Q[$ and there is no steady state in that region. QED

Proof: of proposition 2:

i) If $K_{E} \leq \widetilde{K}_{L}(Q)$, then as $\widetilde{K}_{L}(q)$ is increasing in $q$, then $K_{E}<\widetilde{K}_{L}(q)<\bar{K}_{L}(q)$ for all $q_{t}>Q$ and $q_{t+1}-q_{t}=\beta L_{L}\left(K_{E}-\widetilde{K}_{L}(q)\right)<0$ for all $q_{t}>Q$ and there is no steady state in that region.

ii) If $\widetilde{K}_{L}(Q)<K_{E} \leq \widetilde{K}_{L}(1)$, then as $\widetilde{K}_{L}(q)$ is increasing in $q$, there is a unique steady state $\left.q^{*} \in\right] Q, 1\left[\right.$ given by $\widetilde{K}_{L}\left(q^{*}\right)=K_{E}$. Hence for $q_{t} \leq q^{*}$, we have $K_{E}-\widetilde{K}_{L}\left(q_{t}\right)>0$ . Thus if $K_{E}<\bar{K}_{L}\left(q_{t}\right), q_{t+1}-q_{t}=\beta L_{L}\left(K_{E}-\widetilde{K}_{L}\left(q_{t}\right)\right)>0$. On the other hand if $\bar{K}_{L}\left(q_{t}\right) \leq K_{E}$, we also have from (8) $q_{t+1}-q_{t}>0$. Hence in all cases for $q_{t} \leq q^{*}$ $q_{t+1}-q_{t}>0$. Now for or $q_{t} \geq q^{*}$, we have $K_{E}-\widetilde{K}_{L}\left(q_{t}\right) \leq 0$ and as well $K_{E} \leq \widetilde{K}_{L}(q)<$ $\bar{K}_{L}(q)$. It follows from (8) that $q_{t+1}-q_{t}=\beta L_{L}\left(K_{E}-\widetilde{K}_{L}(q)\right) \leq 0$. This the result that $q^{*}$ is the unique steady state in the set $] Q, 1[$.

iii) If $\widetilde{K}_{L}(1)<K_{E}$, then notice that $\widetilde{K}_{L}(1)=\bar{K}_{L}(1)$ and thus for all $q_{t} \leq 1$ $\bar{K}_{L}\left(q_{t}\right) \leq \bar{K}_{L}(1)<K_{E}$ and from (8) $q_{t+1}-q_{t}>0$ and the unique steady state is $q^{*}=1$. QED 
Figure 1




Figure 2

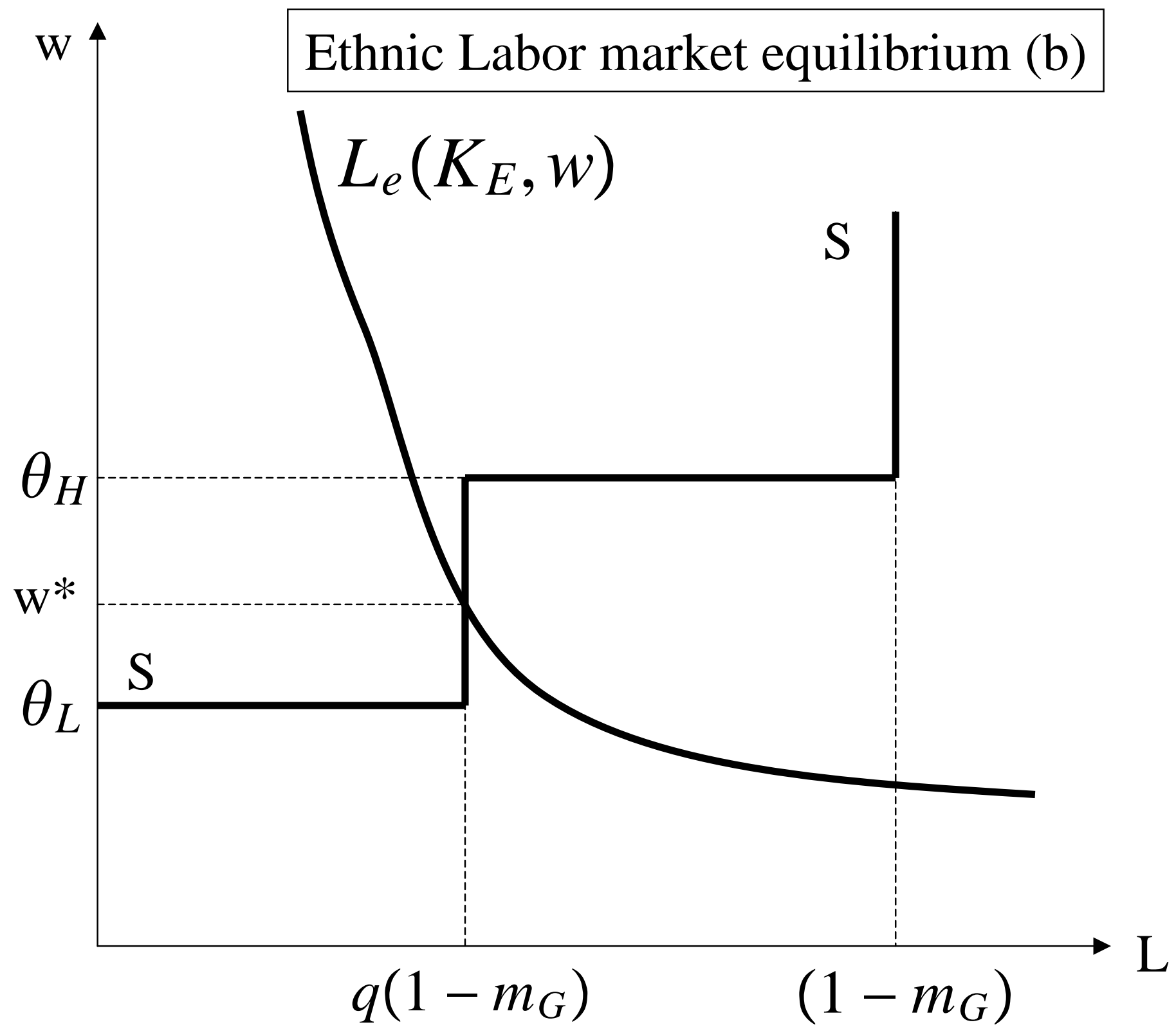


Figure 3

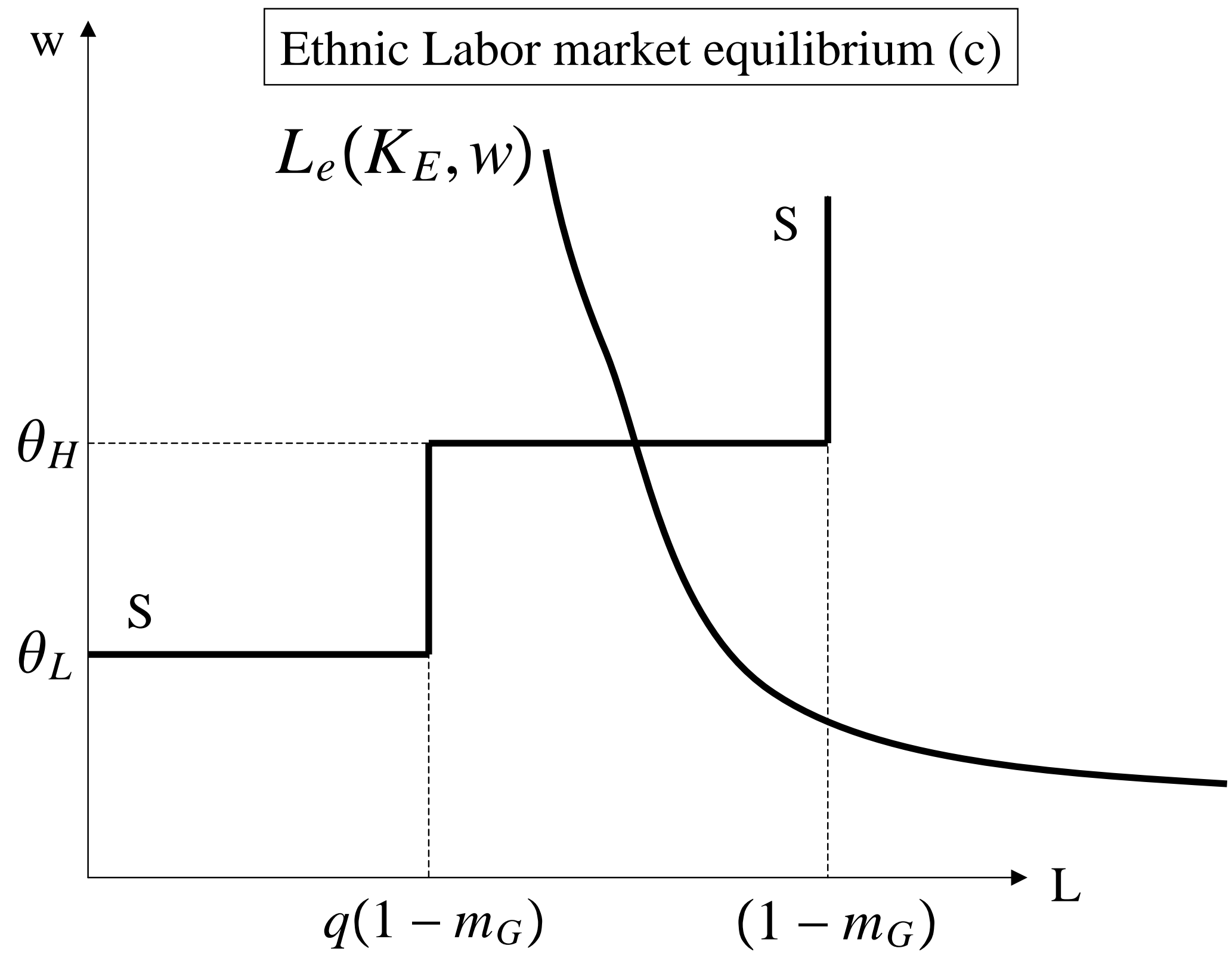


Figure 4

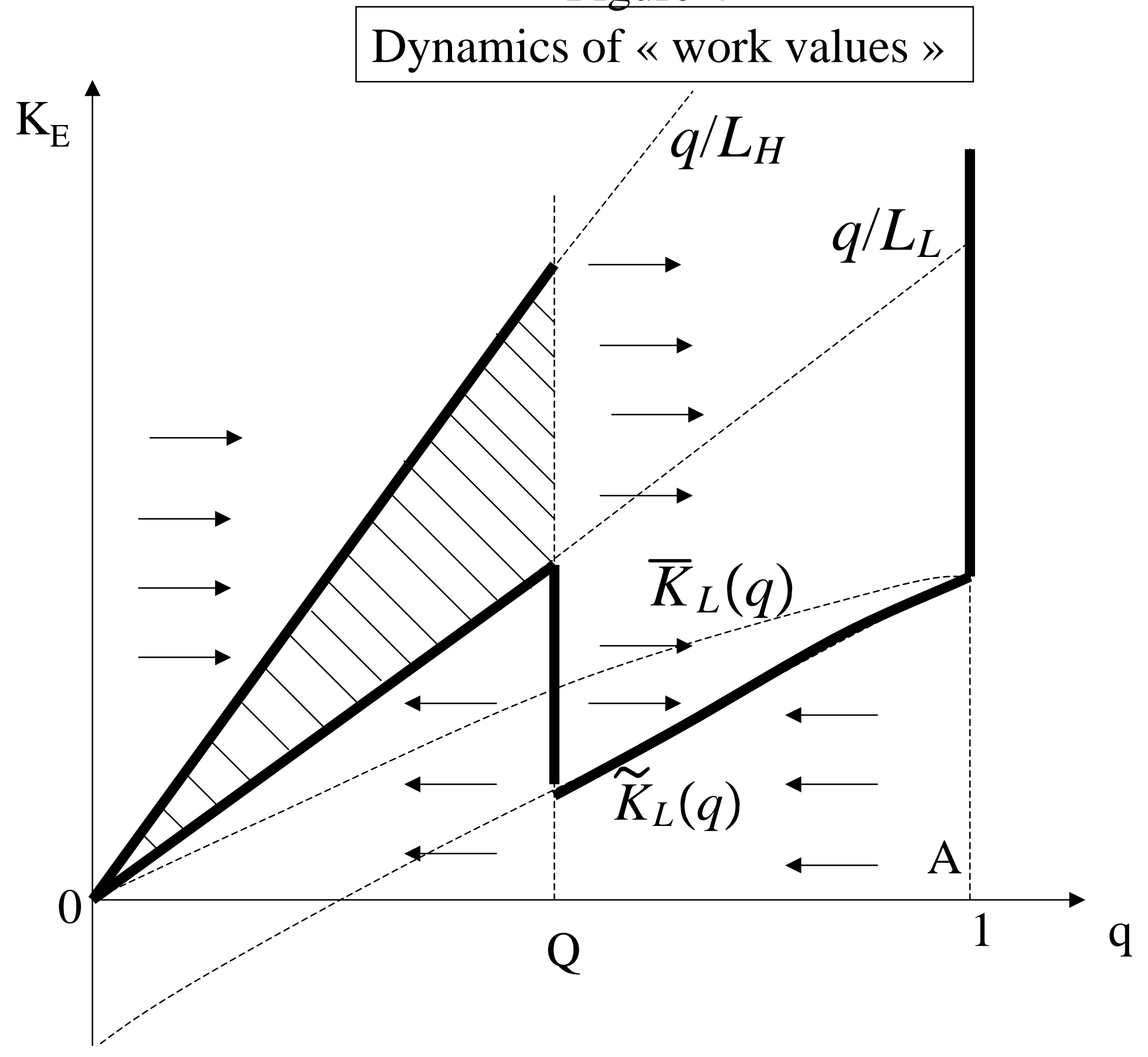


Figure 5

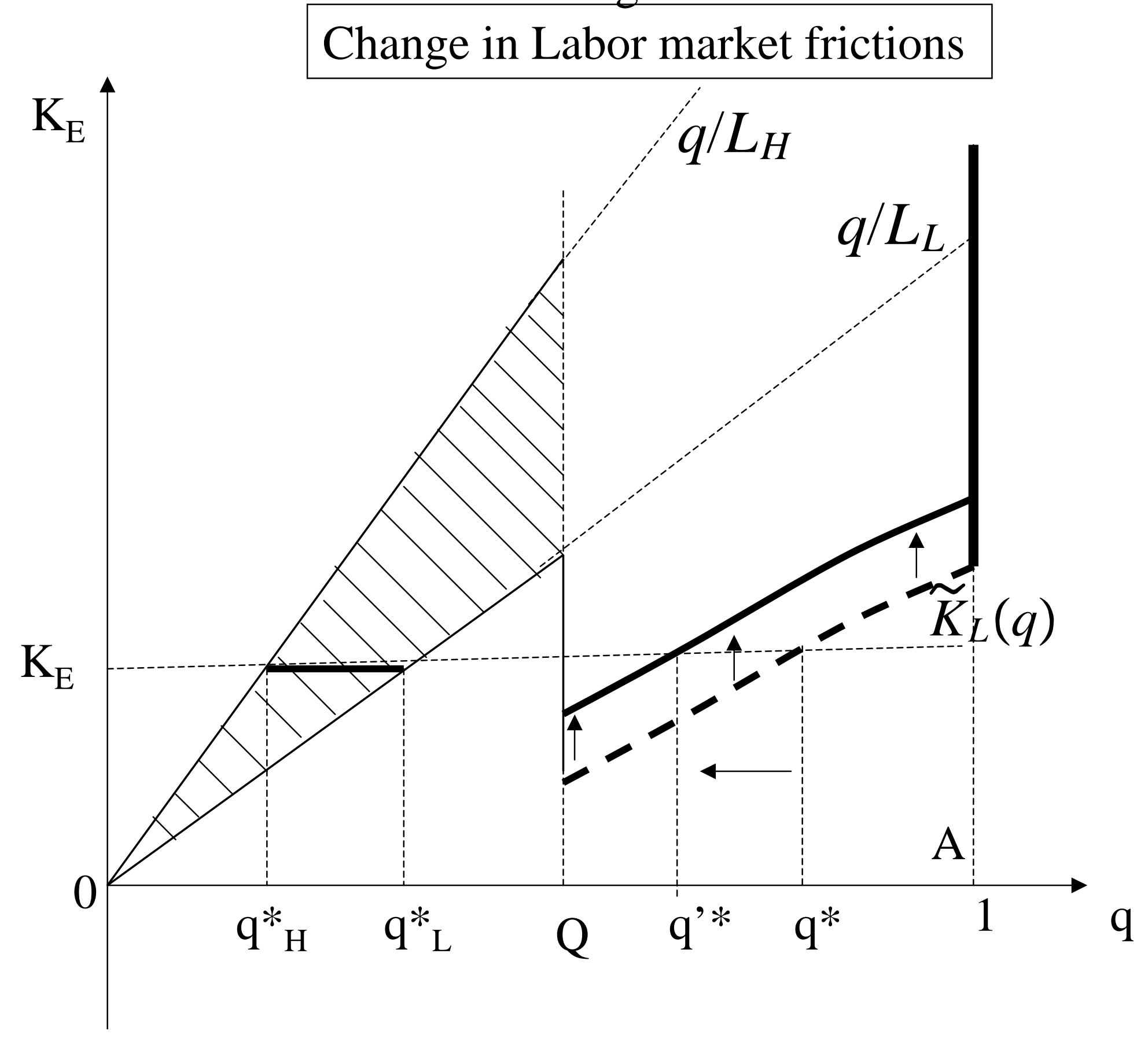




\section{Figure 6}

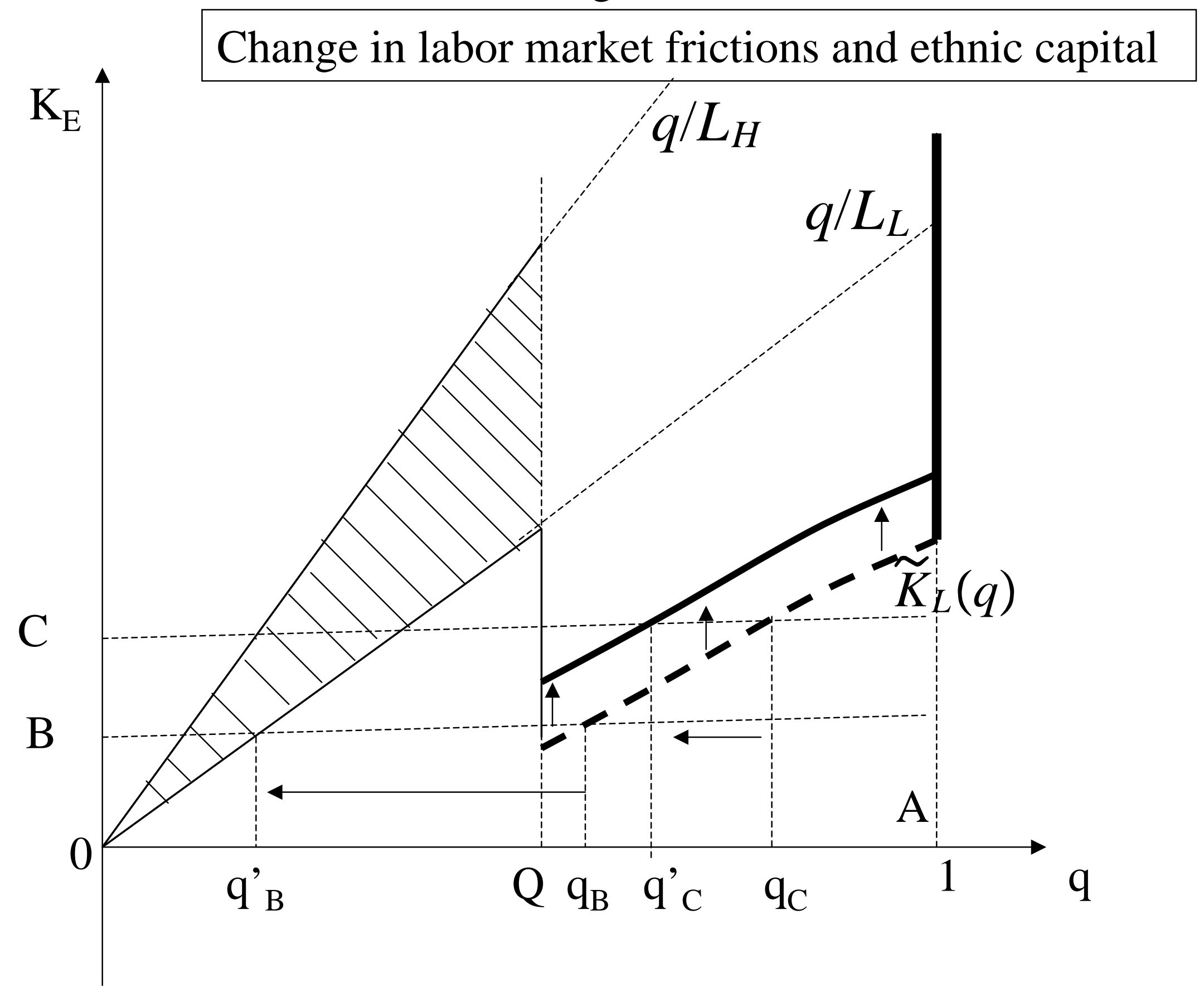




\section{Figure 7}

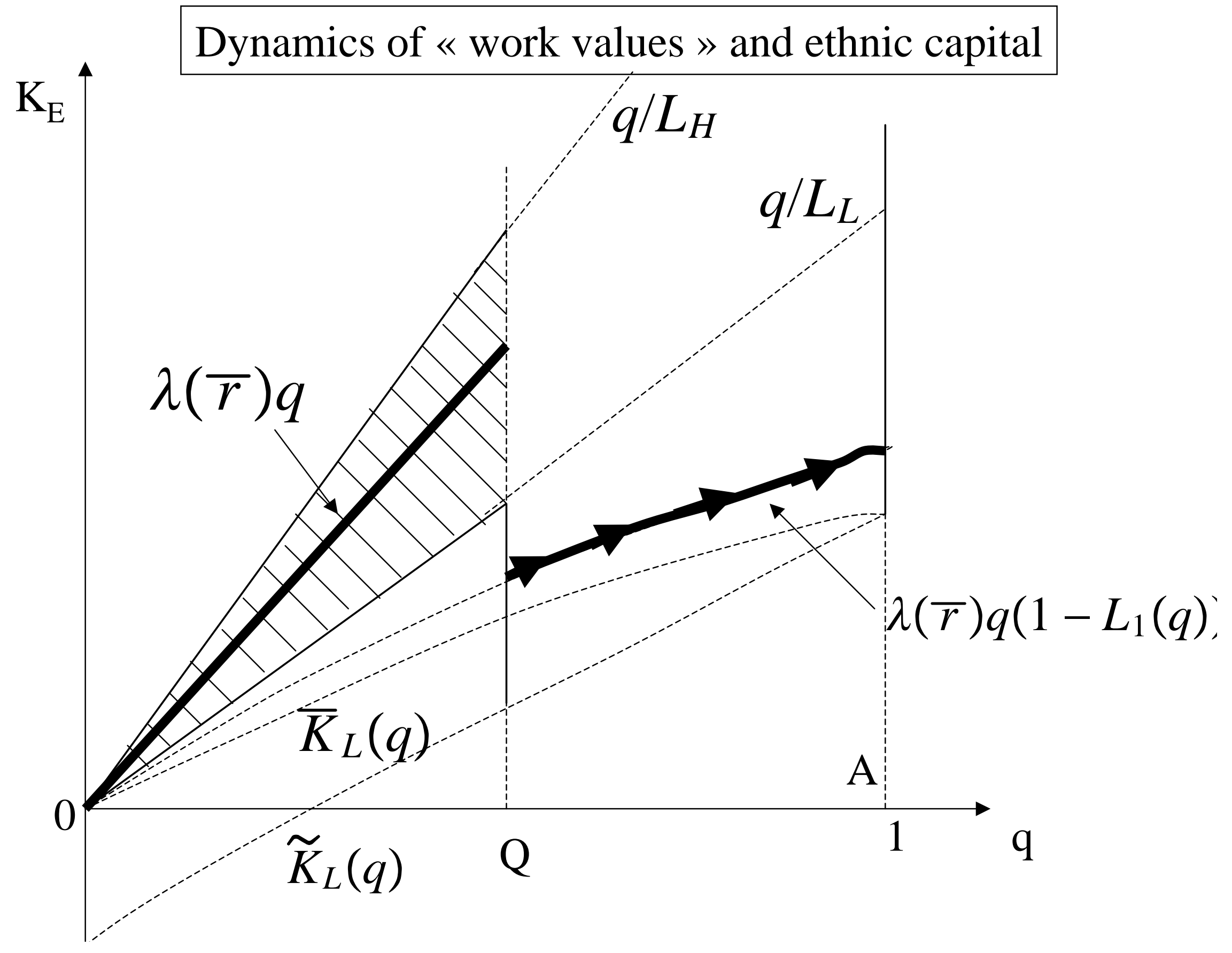


Table 1. The subjective importance of work

\begin{tabular}{lcccc}
\hline$\%$ & $\begin{array}{c}\text { Job is cited among the three } \\
\text { most important items of } \\
\text { identity }\end{array}$ & $\begin{array}{c}\text { Work is more } \\
\text { important }\end{array}$ & $\begin{array}{c}\text { Job satisfaction } \\
\text { motives are } \\
\text { predominant }\end{array}$ & $\begin{array}{c}\text { Job dissatisfaction } \\
\text { motives are } \\
\text { predominant }\end{array}$ \\
\hline Native French & $(1)$ & $(2)$ & $(3)$ & $(4)$ \\
North African origin & 49 & 31 & 49 & 11 \\
South European origin & $\mathbf{3 7}$ & $\mathbf{2 4}$ & $\mathbf{4 6}$ & $\mathbf{1 7}$ \\
\hline
\end{tabular}

$\%$ of respondents : - who quote work in the three most important elements of their identity (column 1), - for whom their job is at least as important as other things (column 2), - who declare that motives of job dissatisfaction outweigh motives of satisfaction (column 3), - who declare that motives of satisfaction dominate (column 4).

Weighted statistics.

Sample : male population aged 18-60 years (column 1), active male population (columns 2-4).

Source : «Histoire de vie- Construction des identités», Insee 2003.

Table 2. Employment status by origin (\%)

\begin{tabular}{lrrrr}
\hline Origin : & France & Maghreb & $\begin{array}{r}\text { Southern } \\
\text { Europe }\end{array}$ & Total \\
\hline \% & 79 & $\mathbf{5 9}$ & 85 & 77 \\
Employed & 6 & $\mathbf{1 4}$ & 2 & 7 \\
Unemployed & 9 & 15 & 6 & 9 \\
Student & 4 & 4 & 2 & 4 \\
Retired & 3 & $\mathbf{6}$ & 3 & 4 \\
Other inactive & & & & \\
Total & 100 & 100 & 100 & 100 \\
\hline
\end{tabular}

Weighted statistics.

Sample : male population aged 18-60 years..

Source : "Histoire de vie- Construction des identités», Insee 2003.

Table 3. Occupation and Origin

\begin{tabular}{lrrrr}
\hline Origin & & \multicolumn{3}{c}{ Southern } \\
Erance & Maghreb & Europe & Total \\
\hline Farmers & 4 & 1 & 2 & 3 \\
Independent & 6 & 5 & 7 & 6 \\
Higher white collar & 16 & 11 & 10 & 16 \\
Intermediate professions & 22 & 20 & 19 & 21 \\
Qualified Employees & 7 & 4 & 4 & 7 \\
Unqualified Employees & 3 & $\mathbf{7}$ & $\mathbf{4}$ & $\mathbf{4}$ \\
Qualified workers & 23 & $\mathbf{2 0}$ & $\mathbf{3 7}$ & 24 \\
Unqualified workers & 10 & $\mathbf{1 9}$ & $\mathbf{1 2}$ & $\mathbf{1 0}$ \\
Inactive & 9 & 14 & 5 & 9 \\
Total & 100 & 100 & 100 & 100 \\
\hline
\end{tabular}

Weighted statistics.

Sample : male population aged 18-60 years.

Source : enquête « Histoire de vie-Construction des identités», Insee 2003.

French classification of occupations (CSP). 
Table 4. The Ethnic Segmentation of the French Labour Market

\section{Logit estimates}

\begin{tabular}{|c|c|c|c|c|c|c|c|}
\hline & 1 & 2 & 3 & 4 & 5 & 6 & 6 \\
\hline & Poor & Income & Indepen & Ident Inacti & Unem & iployed F & Permanent job \\
\hline \multirow[t]{2}{*}{ Age } & $-0.054 * * *$ & $0.050 * * *$ & $0.039 * * *$ & $0.048 * * *$ & $-0.014^{* *}$ & $0.071 * * *$ & $-0.019 * *$ \\
\hline & {$[0.005]$} & [0.003] & [0.008] & {$[0.005]$} & {$[0.006]$} & [0.007] & {$[0.009]$} \\
\hline \multirow[t]{2}{*}{ Children under 11 years } & $-0.458 * * *$ & $0.444 * * *$ & $-0,005$ & $-0.980 * * *$ & $-0.801 * * *$ & $1.095 * * *$ & $=0,08$ \\
\hline & [0.125] & {$[0.085]$} & {$[0.186]$} & [0.127] & {$[0.175]$} & [0.163] & [0.247] \\
\hline \multirow[t]{2}{*}{ Couple } & $-1.159 * * *$ & $0.582 * * *$ & 0,138 & $-0.413^{* * *}$ & $-0,055$ & 0,009 & 0,091 \\
\hline & {$[0.114]$} & {$[0.088]$} & {$[0.177]$} & {$[0.152]$} & {$[0.191]$} & {$[0.175]$} & {$[0.225]$} \\
\hline
\end{tabular}

\section{Education}

- Omitted : none

- secondary
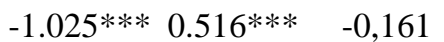

$-0.574 * * *-0.329 *$

$0.516 * * * \quad-0,095$

[0.124] [0.092]

[0.195]

[0.125] [0.176]

[0.182]

[0.232]

- technical long

$-1.143^{* * *} 0.498 * * *$

$0.588 * *$

$-0.543 * * *-0,248$

$0.486 *$

$-0,429$

- higher

[0.182]

[0.131]

[0.252]

[0.192]

[0.247]

[0.251]

[0.353]

$-1.627 * * * 0.917 * * *$

0,253

$-1.382^{* * *}-1.053^{* *}$

$0.738 * * *$

$-0.935 * * *$

[0.146]

[0.203]

[0.161]

[0.218]

[0.204]

[0.294]

Origin

- Omitted: native French with

2 French parents

- Maghreb

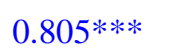

$-0.437 * * *$

$-0.726 * *$

$0.597 * * * \quad 0.661 * * *$

$-0.542 * * *$

[0.139]

[0.104]

[0.290]

[0.148]

[0.181]

[0.187]

- Southern Europe

$-0,215 \quad 0,15$

0,084

$-0.672 * * *-0.700 * *$

0,329

[0.176]

[0.121]

[0.228]

[0.219]

[0.337]

[0.264]

- Other

$0.413^{* * *}$

$-0,116$

$-0,086$

$0.360 * * \quad 0.427 * *$

$-0,242$

$[0.133]$

[0.098]

[0.207]

[0.144] [0.187]

[0.190]

Observations

$\begin{array}{lll}2908 & 2815 & 2342 \\ 0,17 & 0,17 & 0,03 \\ -1459 & -5533 & -759\end{array}$

$2908 \quad 2908$

2445

Pseudo R2

$-1459$

$-759$

$0,12 \quad 0,06$

0,16

log likelihood $-5533$

$-1228 \quad-808$

$-811$

Source : enquête « Histoire de vie- Construction des identités», Insee 2003.

Sample: men, aged 18-60 years old.

Column 1: probability to earn less than the median income (logit model), Column 2: linear regression of the log(individual income), Column 3 : probability to have the statut of independent (logit model), Column 4: probability to be inactive (logit model), Column 5: probability to be unemployed (logit model), probability to have a permanent job (logit model). 
Table 5

Logit regressions of the probability to declare that job is important/ satisfying/ a motive of identity

\begin{tabular}{|c|c|c|c|c|c|c|}
\hline & -1 & -2 & -3 & -4 & -5 & -6 \\
\hline & $\begin{array}{l}\text { Job } \\
\text { dissatisfaction }\end{array}$ & $\begin{array}{l}\text { Job } \\
\text { dissatisfaction }\end{array}$ & $\begin{array}{l}\text { Job } \\
\text { important }\end{array}$ & $\begin{array}{l}\text { Job } \\
\text { important }\end{array}$ & Job identity & Job identity \\
\hline \multirow[t]{2}{*}{ Age } & 0,005 & 0,005 & $0,008^{*}$ & 0,004 & $-0,008^{*}$ & $-0,008^{*}$ \\
\hline & {$[0,009]$} & {$[0,009]$} & {$[0,004]$} & {$[0,005]$} & {$[0,004]$} & {$[0,004]$} \\
\hline \multirow[t]{2}{*}{ Children under 11} & $-0,001$ & 0,006 & 0,024 & 0,034 & $-0,096$ & $-0,097$ \\
\hline & {$[0,190]$} & {$[0,191]$} & {$[0,135]$} & {$[0,145]$} & {$[0,132]$} & {$[0,132]$} \\
\hline \multirow[t]{2}{*}{ Couple } & $-0,01$ & $-0,004$ & $-0,288 * *$ & $-0,274 * * *$ & $0,278 *$ & $0,277^{*}$ \\
\hline & {$[0,177]$} & {$[0,179]$} & {$[0,115]$} & {$[0,106]$} & {$[0,143]$} & {$[0,143]$} \\
\hline \multicolumn{7}{|l|}{ Income category } \\
\hline \multicolumn{7}{|l|}{ Omitted : under the median } \\
\hline \multirow[t]{2}{*}{ average } & $-0,855^{* * *}$ & $-0,869 * * *$ & $-0,109$ & $-0,086$ & $0,715^{* * *}$ & $0,717 * * *$ \\
\hline & {$[0,189]$} & {$[0,202]$} & {$[0,099]$} & {$[0,090]$} & {$[0,087]$} & {$[0,085]$} \\
\hline \multirow[t]{2}{*}{ Richest decile } & $-0,888 * * *$ & $-0,926 * * *$ & $0,335 * * *$ & $0,425 * * *$ & $1,412 * * *$ & $1,419 * * *$ \\
\hline & {$[0,232]$} & {$[0,236]$} & {$[0,123]$} & {$[0,117]$} & {$[0,137]$} & {$[0,135]$} \\
\hline \multicolumn{7}{|l|}{ Education } \\
\hline \multicolumn{7}{|l|}{ Omitted : none } \\
\hline \multirow[t]{2}{*}{ - secondary } & 0,147 & 0,152 & $-0,273^{* *}$ & $-0,313^{* *}$ & $-0,004$ & $-0,004$ \\
\hline & {$[0,189]$} & {$[0,189]$} & {$[0,125]$} & {$[0,137]$} & {$[0,113]$} & {$[0,112]$} \\
\hline \multirow[t]{2}{*}{ - technical long } & 0,235 & 0,255 & $-0,226$ & $-0,346 *$ & $-0,136$ & $-0,14$ \\
\hline & {$[0,204]$} & {$[0,204]$} & {$[0,200]$} & {$[0,192]$} & {$[0,125]$} & {$[0,124]$} \\
\hline \multirow[t]{2}{*}{ - higher } & $-0,106$ & $-0,106$ & $-0,416 * * *$ & $-0,484 * * *$ & $0,266^{* *}$ & $0,267 * *$ \\
\hline & {$[0,249]$} & {$[0,248]$} & {$[0,134]$} & {$[0,141]$} & {$[0,110]$} & {$[0,110]$} \\
\hline \multicolumn{7}{|l|}{ Origin } \\
\hline \multicolumn{7}{|l|}{ Omitted : French natives } \\
\hline \multirow[t]{2}{*}{ North Africa } & $0,569 * *$ & $-1,326 *$ & $-0,373 * * *$ & $1,083 * * *$ & $-0,300 * * *$ & 0,082 \\
\hline & {$[0,255]$} & {$[0,795]$} & {$[0,142]$} & {$[0,410]$} & {$[0,093]$} & {$[0,297]$} \\
\hline \multirow[t]{2}{*}{ Southern Europe } & $-0,253$ & $-2,127^{* *}$ & $-0,151$ & $1,323 * * *$ & 0,035 & 0,413 \\
\hline & {$[0,247]$} & {$[0,849]$} & {$[0,214]$} & {$[0,386]$} & {$[0,163]$} & {$[0,320]$} \\
\hline \multirow[t]{2}{*}{ Other } & 0,153 & $-1,683^{* *}$ & 0,085 & $1,580 * * *$ & 0,042 & 0,41 \\
\hline & {$[0,247]$} & {$[0,806]$} & {$[0,112]$} & {$[0,381]$} & {$[0,145]$} & {$[0,296]$} \\
\hline \multirow[t]{2}{*}{ Father absent or inactive } & $-0,059$ & $-0,049$ & & $-0,028$ & $-0,278$ & $-0,279$ \\
\hline & {$[0,423]$} & {$[0,421]$} & & {$[0,286]$} & {$[0,249]$} & {$[0,249]$} \\
\hline \multirow{2}{*}{$\begin{array}{l}\text { Ratio of ethnic } \\
\text { employers in region }\end{array}$} & & $-0,021^{* *}$ & & $0,017 * * *$ & & 0,004 \\
\hline & & {$[0,010]$} & & {$[0,004]$} & & {$[0,003]$} \\
\hline \multirow[t]{2}{*}{ Constant } & $-1,728 * * *$ & 0,218 & $-0,610 * * *$ & $-2,038 * * *$ & $-0,579 * * *$ & $-0,971 * * *$ \\
\hline & {$[0,417]$} & {$[0,943]$} & {$[0,181]$} & {$[0,444]$} & {$[0,174]$} & {$[0,353]$} \\
\hline Observations & 2025 & 2025 & 2192 & 2025 & 2651 & 2651 \\
\hline Pseudo R2 & 0,03 & 0,03 & 0,01 & 0,01 & 0,05 & 0,05 \\
\hline log likelihood & -690 & -689 & -1347 & -1237 & -1739 & -1739 \\
\hline
\end{tabular}

Sample: men, aged 18-60 years old. ${ }^{* * *}$ significant at 1\%, ${ }^{* *}$ significant at 5\%, * significant at $10 \%$. Robust significant standard errors in bracket, cluster (region),

Columns 1 and 2: probability to declare that motives of job dissatisfaction dominant; - columns 3 and 4 : probability to declare that job is at least as important as other aspects of life; - column 5 and 6: probability to quote work in the three most important elements of their identity. 


\section{Table 6}

\section{Logit regressions of the probability to be inactive}

\begin{tabular}{lll}
\hline & $\mathbf{1}$ & $\mathbf{2}$ \\
Age & Inactive & Inactive \\
& $0,074^{* * *}$ & $0,074^{* * *}$ \\
Children under 11 & {$[0,006]$} & {$[0,006]$} \\
& $-0,387^{* *}$ & $-0,387^{* *}$ \\
Couple & {$[0,153]$} & {$[0,152]$} \\
& $-0,571^{* * *}$ & $-0,571^{* * *}$ \\
& {$[0,156]$} & {$[0,157]$}
\end{tabular}

\section{Income category}

Omitted : under the median

average

$-1,987 * * *$

$-1,987 * * *$

Richest decile

$[0,159]$

$[0,160]$

$-2,377 * * *$

$-2,378 * * *$

$[0,286]$

$[0,294]$

\section{Education}

Omitted : none

- secondary

$-0,174$

$-0,174$

$[0,171]$

$[0,170]$

- technical long

$-0,072$

$-0,071$

$[0,165]$

$[0,168]$

- higher

$-0,708 * * *$

$-0,708 * * *$

$[0,258]$

$[0,256]$

\section{Origin}

Omitted : French natives

$\begin{array}{lll}\text { North Africa } & 0,330^{* *} & 0,269 \\ & {[0,144]} & {[0,963]} \\ \text { Southern Europe } & -0,629^{*} & -0,689 \\ & {[0,327]} & {[1,041]} \\ \text { Other } & 0,132 & 0,073 \\ & {[0,233]} & {[0,781]} \\ \text { Father absent or inactive } & 0,607^{* * *} & 0,607^{* * *} \\ & {[0,222]} & {[0,221]} \\ \text { Ratio of ethnic } & & -0,001 \\ \text { employers in region } & & {[0,010]} \\ & & \\ \text { Constant } & -2,837^{* * *} & -2,774 * * * \\ & {[0,248]} & {[0,868]} \\ \text { Observations } & 2651 & 2651 \\ \text { Pseudo R2 } & 0,22 & 0,22 \\ \text { log likelihood } & -952 & \end{array}$

Sample: men, aged 18-60 years old.

*** significant at $1 \%$, ** significant at 5\%, * significant at 10\%.Robust significant standard errors in bracket, cluster (region),

Columns 7 and 8: probability to be inactive. 


\section{Annex: data, constructed variables and descriptive statistics}

\section{The French survey of the population in 1999.}

The French census of the population is realized by the national statistical office (INSEE). The whole population is surveyed, i.e. 58 million inhabitants. We have used the latest available 1999 census. Because nationality and immigration are considered to be "sensitive » topics, we have had access to somewhat aggregated data: we have used the NAT3E table, which details the total number of individuals by nationality * region * professional occupation. The census only distinguishes immigrants of the first generation, i.e. persons who were born with a foreign nationality. We have retained four categories of population: individuals who were born French, those who were born with a North African nationality (Algeria, Morocco, Tunisia), those who were born with a south European nationality (Italy, Portugal, Spain) and the residual category of immigrants.

Table A1. Composition of the French population in the 1999 census

\begin{tabular}{|c|c|c|c|c|c|}
\hline Region & Born French & Maghreb & South Europe & Other & Total \\
\hline ILE DE FRANCE & 8906217 & 593322 & 533737 & 917860 & \\
\hline CHAMPAGNE-ARDENNE & 1251961 & 27380 & 28947 & 33914 & \\
\hline PICARDIE & 1746615 & 32958 & 31699 & 45833 & \\
\hline HAUTE NORMANDIE & 1699395 & 28014 & 18206 & 34824 & \\
\hline CENTRE & 2275545 & 45211 & 60247 & 58959 & \\
\hline BASSE NORMANDIE & 1386097 & 7894 & 7088 & 21357 & \\
\hline BOURGOGNE & 1494437 & 33113 & 47557 & 35300 & \\
\hline NORD PASDE CALAIS & 3748693 & 95298 & 49208 & 102672 & \\
\hline LORRAINE & 2068349 & 54825 & 92908 & 93941 & \\
\hline ALSACE & 1529602 & 46748 & 44401 & 112981 & \\
\hline FRANC HE COMTE & 1025590 & 30220 & 26663 & 34784 & \\
\hline PAYSDE LA LOIRE & 3142814 & 22154 & 16838 & 40978 & \\
\hline BRETAGNE & 2850783 & 10262 & 10700 & 35433 & \\
\hline POITOU CHARENTES & 1592380 & 9056 & 17156 & 21861 & \\
\hline AQUITAINE & 2703250 & 42733 & 107197 & 55773 & \\
\hline MIDI PYRENEES & 2332888 & 50262 & 110813 & 58733 & \\
\hline UMOUSIN & 676919 & 7493 & 13034 & 13346 & \\
\hline RHONE ALPES & 5009511 & 201541 & 233080 & 201715 & \\
\hline AUVERGNE & 1231187 & 15229 & 40126 & 22114 & \\
\hline LANGUEDOC ROUSSIШON & 2038746 & 85913 & 114537 & 57161 & \\
\hline $\begin{array}{l}\text { PROVENCE ALPES C OTE D } \\
\text { AZJR }\end{array}$ & 3964700 & 213740 & 182401 & 145412 & \\
\hline CORSE & 226530 & 18596 & 11183 & 3840 & \\
\hline Total & 52902209 & 1671962 & 1797726 & 2148791 & 58520688 \\
\hline en \% & 90,4 & 2,9 & 3,1 & 3,7 & 100 \\
\hline
\end{tabular}

Source : INSEE, French census of the population, table NAT3E, 1999.

First column : individuals who were born French, second column : people born with North African nationality (Algeria, Morocco, Tunisia), third column: people born with South European nationality (Italy, Spain, Portugal), fourth column: Other origin.. 


\begin{tabular}{|c|c|c|c|}
\hline & $\%$ Native French & $\begin{array}{l}\% \text { immigrants } \\
\text { from North Africa }\end{array}$ & $\begin{array}{l}\text { \% immigrants from } \\
\text { Southern Europe }\end{array}$ \\
\hline & \multicolumn{3}{|c|}{ among the employers of the region } \\
\hline ILE DE FRANCE & 78 & 5,9 & 6,1 \\
\hline CHAMPAGNE-ARDENNE & 95 & 0,7 & 2,2 \\
\hline PICARDIE & 94 & 1,0 & 2,3 \\
\hline HAUTE NORMANDIE & 96 & 0,9 & 1,4 \\
\hline CENTRE & 94 & 0,6 & 2,7 \\
\hline BASSE NO RMANDIE & 97 & 0,3 & 0,6 \\
\hline BOURG OGNE & 94 & 0,6 & 3,0 \\
\hline NORD PASDE CALAIS & 95 & 1,2 & 1,7 \\
\hline LORRAINE & 90 & 0,9 & 4,2 \\
\hline ALSACE & 89 & 1,3 & 3,2 \\
\hline FRANCHE COMTE & 94 & 0,7 & 2,5 \\
\hline PAYSDE LA LOIRE & 98 & 0,4 & 0,5 \\
\hline BRETAGNE & 98 & 0,3 & 0,6 \\
\hline POITOU CHARENTES & 97 & 0,3 & 1,0 \\
\hline AQUITAINE & 94 & 0,6 & 3,6 \\
\hline MIDI PYRENEES & 93 & 0,9 & 4,1 \\
\hline LIMOUSIN & 96 & 0,4 & 2,1 \\
\hline RHONE ALPES & 91 & 1,4 & 4,2 \\
\hline AUVERGNE & 95 & 0,5 & 3,3 \\
\hline LANGUEDOC ROUSSIШON & 91 & 1,6 & 4,7 \\
\hline PROVENCE ALPES COTE D AZUR & 90 & 2,5 & 3,9 \\
\hline CORSE & 92 & 1,6 & 5,1 \\
\hline
\end{tabular}

Source : INSEE,French census of the population, table NAT3E, 1999. 
Table A3. Structure of the population : 1. Native French

\begin{tabular}{|c|c|c|c|c|}
\hline & $\%$ inactive & \% employees & \% employers & $\begin{array}{l}\text { \% employers and } \\
\text { independent } \\
\text { workers }\end{array}$ \\
\hline & \multicolumn{4}{|c|}{ among the total native French population of the region } \\
\hline ILE DE FRANCE & 56 & 40 & 1,9 & 3,7 \\
\hline CHAMPAGNE-ARDENNE & 61 & 34 & 2,2 & 4,4 \\
\hline PICARDIE & 61 & 35 & 1,8 & 3,6 \\
\hline HAUTE NORMANDIE & 61 & 35 & 1,8 & 3,5 \\
\hline CENTRE & 60 & 35 & 2,1 & 4,4 \\
\hline BASSE NORMANDIE & 61 & 33 & 2,2 & 5,0 \\
\hline BOURGOGNE & 61 & 33 & 2,2 & 4,8 \\
\hline NORD PASDE CALAIS & 65 & 32 & 1,4 & 2,8 \\
\hline LORRAINE & 61 & 35 & 1,7 & 3,2 \\
\hline ALSACE & 56 & 40 & 2,0 & 3,4 \\
\hline FRANC HE COMTE & 59 & 36 & 2,0 & 4,3 \\
\hline PAYSDE LA LOIRE & 60 & 35 & 2,1 & 4,7 \\
\hline BRETAGNE & 61 & 33 & 2,3 & 5,2 \\
\hline POITOU CHARENTES & 62 & 32 & 2,4 & 5,4 \\
\hline AQ UITAINE & 61 & 32 & 2,5 & 5,5 \\
\hline MIDI PYRENEES & 61 & 32 & 2,4 & 6,1 \\
\hline UMOUSIN & 62 & 32 & 2,2 & 5,8 \\
\hline RHONE ALPES & 59 & 36 & 2,3 & 4,8 \\
\hline AUVERGNE & 61 & 32 & 2,2 & 5,9 \\
\hline LANGUEDOC ROUSSIШON & 66 & 29 & 2,4 & 5,5 \\
\hline $\begin{array}{l}\text { PROVENCE ALPES COTE D } \\
\text { AZUR }\end{array}$ & 64 & 31 & 2,3 & 4,8 \\
\hline CORSE & 67 & 27 & 2,8 & 6,3 \\
\hline
\end{tabular}

Source : INSEE,French census of the population, table NAT3E, 1999. 
Table A3. continued. Structure of the population 2. immigrants from North Africa

\begin{tabular}{|c|c|c|c|c|}
\hline & $\begin{array}{l}\text { \% inactive } \\
\text { among the }\end{array}$ & $\begin{array}{l}\text { \% employees } \\
\text { tal immigrant }\end{array}$ & $\begin{array}{l}\text { \% employers } \\
\text { rom North Af }\end{array}$ & $\begin{array}{l}\text { \% employers and } \\
\text { independent } \\
\text { workers } \\
\text { a in the region }\end{array}$ \\
\hline ILE DE FRANCE & 61 & 34 & 2,1 & 4,6 \\
\hline CHAMPAG NE-ARDENNE & 72 & 26 & 0,7 & 1,8 \\
\hline PICARDIE & 71 & 27 & 1,0 & 2,3 \\
\hline HAUTE NORMANDIE & 72 & 25 & 1,0 & 2,5 \\
\hline CENTRE & 71 & 27 & 0,7 & 1,8 \\
\hline BASSE NORMANDIE & 70 & 27 & 1,2 & 2,7 \\
\hline BOURGOGNE & 71 & 27 & 0,7 & 1,7 \\
\hline NORD PASDE CALAIS & 78 & 20 & 0,7 & 2,1 \\
\hline LORRAINE & 73 & 25 & 0,7 & 1,4 \\
\hline ALSACE & 65 & 33 & 1,0 & 2,1 \\
\hline FRANC HE COMTE & 70 & 28 & 0,5 & 1,4 \\
\hline PAYSDE LA LOIRE & 68 & 29 & 1,1 & 2,6 \\
\hline BRETAGNE & 65 & 31 & 1,9 & 4,2 \\
\hline POITOU CHARENTES & 69 & 28 & 1,4 & 3,0 \\
\hline AQUITAINE & 70 & 27 & 1,1 & 2,5 \\
\hline MIDI PYRENEES & 71 & 26 & 1,1 & 2,9 \\
\hline UMOUSIN & 73 & 24 & 0,9 & 2,0 \\
\hline RHONE ALPES & 68 & 30 & 0,9 & 2,2 \\
\hline AUVERGNE & 71 & 26 & 1,0 & 2,4 \\
\hline LANGUEDOC ROUSSILON & 76 & 21 & 1,0 & 2,2 \\
\hline PROVENCE ALPES COTE D AZUR & 73 & 24 & 1,2 & 2,6 \\
\hline CORSE & 73 & 25 & 0,6 & 1,6 \\
\hline
\end{tabular}

Source : INSEE,French census of the population, table NAT3E, 1999. 
Table A3. continued. Structure of the population 3. immigrants from Southern Europe (\%)

\begin{tabular}{|c|c|c|c|c|}
\hline & $\begin{array}{l}\% \text { inactive } \\
\text { among the to }\end{array}$ & $\begin{array}{l}\text { \% employees } \\
\text { otal immigrant }\end{array}$ & $\begin{array}{l}\text { \% employers } \\
\text { from Southern }\end{array}$ & $\begin{array}{c}\text { \% employers and } \\
\text { independent workers } \\
\text { Europe in the region }\end{array}$ \\
\hline ILE DE France & 45 & 50 & 2,4 & 4,6 \\
\hline CHAMPAG NE-ARDENNE & 52 & 44 & 2,2 & 3,8 \\
\hline PICARDIE & 49 & 47 & 2,4 & 4,2 \\
\hline HAUTE NORMANDIE & 52 & 44 & 2,4 & 3,9 \\
\hline CENTRE & 47 & 48 & 2,3 & 4,0 \\
\hline BASSE NORMANDIE & 58 & 37 & 2,7 & 4,7 \\
\hline BOURG OG NE & 51 & 44 & 2,2 & 4,1 \\
\hline NORD PASDE CALAIS & 55 & 41 & 1,9 & 3,2 \\
\hline LORRAINE & 60 & 37 & 1,7 & 2,9 \\
\hline ALSACE & 46 & 50 & 2,5 & 3,9 \\
\hline FRANCHE COMTE & 52 & 44 & 2,0 & 3,4 \\
\hline PAYSDE LA LOIRE & 52 & 44 & 2,1 & 3,9 \\
\hline BRETAG NE & 54 & 38 & 3,9 & 7,1 \\
\hline POITOU C HARENTES & 55 & 40 & 2,4 & 4,6 \\
\hline AQUITAINE & 60 & 35 & 2,4 & 5,0 \\
\hline MIDI PYRENEES & 65 & 30 & 2,2 & 4,9 \\
\hline UMOUSIN & 51 & 43 & 2,5 & 5,3 \\
\hline RHONE ALPES & 54 & 41 & 2,3 & 4,4 \\
\hline AUVERGNE & 50 & 45 & 2,4 & 4,3 \\
\hline LANGUEDOC ROUSSILLON & 69 & 26 & 2,2 & 4,8 \\
\hline PRO VENCE ALPES COTE D AZUR & 70 & 25 & 2,1 & 4,4 \\
\hline CORSE & 64 & 30 & 3,1 & 5,8 \\
\hline
\end{tabular}




\section{The survey « Histoire de Vie »}

The survey « Histoire de vie » contains information about the nationality and the country of birth of the respondents, as well as those of their two parents. It also contains information about the three main mother tongues of the respondents. We have classified as immigrants of the first or second (or more) generation all respondents whose nationality, or parents' nationality, or mother tongue, indicated a foreign origin. We have constructed four categories of people. Persons who were born French in France, with two French parents/ immigrants from North Africa/ immigrants from Southern Europe/Other. The structure of the sample of respondents aged from 18 to 60 years old, is as follows:

Table A4. Composition of the population 18-60 years old (Histoire de Vie)

\begin{tabular}{|c|c|c|c|c|c|c|}
\hline & \multicolumn{3}{|c|}{ Whole population 18- 60 years } & \multicolumn{3}{|c|}{ Men 18- 60 years } \\
\hline & number & $\%$ & Weighted \% & number & $\%$ & Weighted \% \\
\hline French & 4215 & 65,9 & 75,94 & 1928 & 66,3 & 76,8 \\
\hline Maghreb & 724 & 11,3 & 8,2 & 341 & 11,7 & 7,7 \\
\hline Southern Europe & 564 & 8,8 & 5,3 & 245 & 8,4 & 5,1 \\
\hline Other & 891 & 13,9 & 10,57 & 394 & 13,6 & 10,4 \\
\hline Total & 6394 & 100.00 & 100.00 & 2908 & 100.00 & 100.00 \\
\hline
\end{tabular}


Table A5. Average income of men by origin/region

\begin{tabular}{|c|c|c|c|c|}
\hline Region & French & Maghreb & South Europe & Other \\
\hline ILE DE FRANCE & 26408 & 23148 & 22866 & 20281 \\
\hline \multicolumn{5}{|l|}{ CHAMPAGNE- } \\
\hline ARDENNE & 20006 & 17192 & 12613 & 16513 \\
\hline PICARDIE & 17252 & 13543 & 22707 & 20046 \\
\hline HAUTE NORMANDIE & 19342 & 11695 & 17928 & 24453 \\
\hline CENTRE & 18444 & 24381 & 21150 & 25760 \\
\hline BASSE NORMANDIE & 16360 & 19174 & 11708 & 20233 \\
\hline BOURGOGNE & 18822 & 6266 & 19712 & 21422 \\
\hline \multicolumn{5}{|l|}{ NORD PASDE } \\
\hline CALAIS & 16547 & 10025 & 14468 & 17548 \\
\hline LORRAINE & 19174 & 12303 & 18568 & 17086 \\
\hline ALSACE & 21559 & 18054 & 19223 & 20246 \\
\hline FRANC HE COMTE & 17789 & 12686 & 16602 & 18073 \\
\hline PAYSDE LA LOIRE & 18339 & 15100 & 13949 & 18620 \\
\hline BRETAG NE & 18837 & 14158 & 57379 & 14647 \\
\hline POITOU CHARENTES & 16374 & 21708 & 12797 & 21966 \\
\hline AQUITAINE & 18172 & 22024 & 17182 & 13547 \\
\hline MIDI PYRENEES & 18920 & 16981 & 15906 & 21913 \\
\hline UMOUSIN & 15759 & 12417 & 15751 & 14818 \\
\hline RHONE ALPES & 21249 & 15108 & 16704 & 19868 \\
\hline AUVERG NE & 20035 & 12473 & 16797 & 15080 \\
\hline \multicolumn{5}{|l|}{ LANGUEDOC } \\
\hline ROUSSILLON & 16176 & 14585 & 12835 & 17783 \\
\hline \multicolumn{5}{|l|}{ PROVENCE ALPES } \\
\hline $\begin{array}{l}\text { CORSE } \\
\text { COR }\end{array}$ & $\begin{array}{l}20933 \\
14332\end{array}$ & $\begin{array}{l}14950 \\
14949\end{array}$ & $\begin{array}{r}19 / 14 \\
9457\end{array}$ & $\angle 2556$ \\
\hline Ecart-type & 2547 & 4458 & 9383 & 3265 \\
\hline
\end{tabular}

Source : « Histoire de Vie », INSEE, 2003

Sample: male population, 18 to 60 years old.

Weighted statistics. 
Tableau A6. Share of inactive people by origin/region

\begin{tabular}{|c|c|c|c|c|}
\hline & French & Maghreb & Southern Europe & Other \\
\hline ILE DE FRANCE & 12 & 22 & 4 & 22 \\
\hline CHAMPAGNE-ARDENNE & 14 & 8 & 4 & 7 \\
\hline PICARDIE & 17 & 28 & 0 & 2 \\
\hline HAUTE NORMANDIE & 12 & 49 & 11 & 6 \\
\hline CENTRE & 14 & 6 & 0 & 22 \\
\hline BASSE NORMANDIE & 11 & 54 & 0 & 0 \\
\hline BOURGOGNE & 10 & 39 & 3 & 23 \\
\hline NORD PASDE CALAIS & 9 & 22 & 13 & 18 \\
\hline LORRAINE & 13 & 69 & 11 & 37 \\
\hline ALSACE & 16 & 37 & 0 & 22 \\
\hline FRANC HE COMTE & 19 & 22 & 0 & 25 \\
\hline PAYSDE LA LOIRE & 8 & 52 & 0 & 37 \\
\hline BRETAGNE & 13 & 5 & 0 & 18 \\
\hline POITOU CHARENTES & 20 & 54 & 14 & 0 \\
\hline AQUITAINE & 21 & 41 & 5 & 4 \\
\hline MIDI PYRENEES & 13 & 16 & 0 & 33 \\
\hline UMOUSIN & 8 & 100 & 0 & 34 \\
\hline RHONE ALPES & 8 & 17 & 16 & 29 \\
\hline AUVERGNE & 10 & 21 & 0 & 48 \\
\hline LANGUEDOC ROUSSIШON & 17 & 11 & 6 & 21 \\
\hline PROVENCE ALPES COTE D AZUR & 14 & 17 & 34 & 1 \\
\hline CORSE & 15 & 51 & 22 & na \\
\hline
\end{tabular}

Source : « Histoire de vie », INSEE, 2003

Weighted statistics.

Sample :male population, 18 to 60 years old.. 


\section{Questions of the survey "Histoire de vie"}

\section{Questions asked to the whole sample :}

First, among the topics that we have been talking about, which are the three topics that best correspond to you, that best describe who you are? (maximum 3 answers, the order counts).

- $\quad$ Your family

- $\quad$ The places you are attached to ?

- Your job, your professional situation, your education

- $\quad$ Your friends

- A passion, a regular leisure activity

- Your physical appearance

- $\quad$ A health problem, a handicap

- Your geographical origin

- Your political or religious opinions and commitment

- $\quad$ Something else

During the last 12months, how frequently have you been meeting, at your place or at theirs, or outside, friends of yours (or of your spouse)?

Among those friends that you have just quoted, are some of them:

Many possible answers, tick the chosen answers.

1. neighbors ?

2. former school-mates ?

3. childhood friends ?

4. persons coming from the same place as you ?

5. people with whom you share the same values, the same way of living ?

6. people of the same profession, or of the same professional group as you ?

7. none of these categories of people

When you were 15 years old, did your father (or the man that you consider like your father) work?

1. Yes

2. No, he did not work at that time

3. No, he never worked

4. Father unknown or absent

\section{Questions asked to the sub-sample of active persons, i.e. 4387 individuals.}

Nowadays, would yo usay that in your life in general, your job is:

1. more important than anything else

2. very important, but with parity with other things (family life, personal life, social life, etc.)

3. is quite important but less important than other things (family life, personal life, social life, et.)

4. is not important

And now, everything considered, as a whole, in your current job, what is dominant?

1. Satisfaction motives

2. Dissatisfaction motives

3. Satisfaction and dissatisfaction motives balance each other. 